\title{
Rio dos currais: paisagem material e rede urbana do rio São Francisco nas capitanias da Bahia e Pernambuco'.
}

\section{Esdras Arraes ${ }^{2}$}

RESUMO: Considerado como eixo de penetração e de expansão dos domínios americanos de Portugal, o rio São Francisco apresentou, ao longo do período colonial, uma particular experiência de urbanização em sua região e uma paisagem material derivadas de diferentes "encontros culturais". Partindo dessa premissa, este ensaio busca interpretar, por meio das evidências materiais deixadas no território (caminhos, pousos, fazendas, igrejas e povoações de distintos níveis e perfis), as redes urbanas (eclesiástica e civil) do vale sanfranciscano, pertencente às capitanias da Bahia e Pernambuco. Com foco nos sertões dessas unidades administrativas, se propõe a descortinar a política de urbanização da Coroa lusitana implementada por meio da oficialização de núcleos urbanos, estrategicamente implantados no território, para o favorecimento do Estado português e da lgreja católica. Põe luz nos agentes, nas redes de relações e hierarquias sociais, verificando suas implicações econômicas, políticas e culturais na urbanização e na paisagem cultural do "rio dos currais". PALAVRAS-CHAVE: Brasil - Período Colonial. Urbanização. Rede urbana. Paisagem material. Pecuária. Rio São Francisco

ABSTRACT: Considered as the axis of penetration and expansion of the american dominions of Portugal, the São Francisco River presented, over colonialism, a peculiar urbanization and material landscape derived from differents "cultural encounters". Following this premise, this essay seeks to interpret, through physical evidences left in the territory (roads, landings, farms, churches and villages of different levels and profiles), the urban webs (civil and ecclesiasticall) of the valley of river San Francisco belonging to captaincies of Bahia and Pernambuco. Focousing on hinterland these administrative units, aims to uncover the urbanization policy of the portuguese Crown trhough formalization of urban centers, strategically deployed in the territory, for favoring the Portuguese State and Catholic Church. Puts light on the agents, networks of relationships and social hierarchies, checking their implications economic, political and cultural in the urbanization and cultural landscape of the "River of the corrals". KEYWORDS: Colonialism. Urbanization. Urban webs. Material landscape. Cattle. São Francisco River.
1. Este texto procede de uma pesquisa mais ampla, em nível de doutorado, realizada junto à Faculdade de Arquitetura e Urbanismo da Universidade de São Paulo (FAUUSP), sob orientação da Profa. Dra. Beatriz P. Siqueira Bueno. Agradeço a Fundação de Amparo à Pesquisa do Estado de São Paulo (FAPESP) pelo apoio concedido à realização desta investigação.

2. Arquiteto e Urbanista, doutorando na Faculdade de Arquitetura e Urbanismo da Universidade de São Paulo (FAUUSP). Bolsista FAPESP. E-mail: <esdrasarraes@usp.br>; <esdras_arraes@yahoo.com.br>. 
3. Cf. Theodoro Sampaio (1905, p 11).

4. Os "línguas" eram índios participantes no devassamento e conhecimento do território através do seu auxílio como intérpretes dos colonizadores.

5. Ver João Justiniano da Fonseca (1996, p. 51).

6. Ver Basílio de Magalhães (1944, p. 238)

7. Cf. André João Antonil (1982, p. 94, 96).

8. Cf. Peter Burke (2005, p. 154).
Introdução

O rio São Francisco, como um Oasis no deserto, através dos sertões adustos da Bahia ao Ceará, de Pernambuco ao Piauhy, é, na verdade, a terra da promissão e o refugio daquelles povos assolados pela seca prolongada e periódica.

Theodoro Sampaio ${ }^{3}$

Irrigando as áreas ribeirinhas desde a capitania de Minas Gerais, passando pelas áreas de campos e caatinga da Bahia e Pernambuco, até chegar em sua foz atlântica, o rio São Francisco foi antes de tudo um eixo condutor de povoamento dos sertões da América portuguesa, fator de dilatação das fronteiras do Brasil Colonial e estruturador de uma complexa e dinâmica divisão social e territorial do trabalho, percebida em sua hierárquica rede urbana. Assentamentos humanos de diferentes níveis e perfis se beneficiaram políitico, econômico e socialmente por estarem localizados em suas margens. De certa maneira, o curso fluvial sanfranciscano garantia facilidade de comunicação e diminuição da dispersão latente em que viviam os moradores mais interioranos nos séculos coloniais.

Antes dos sertanistas devassarem os sertões do Brasil, diferentes tribos indígenas habitavam aquela vasta área, facilitando o trabalho dos portugueses, haja vista as trilhas e caminhos elaborados pelos nativos e a existência dos "línguas" ${ }^{4}$ que auxiliavam o devassamento do incógnito interior. Além de colaborar para a transformação da paisagem territorial sertaneja, os índios, em associação com os colonizadores (nesta categoria enquadramos os missionários das distintas ordens religiosas) contribuíram para a formação da teia de aldeamentos missioneiros, compondo um dos conjuntos do sistema urbano implantado ao longo do curso fluvial do São Francisco. No chamado "Serrão de Rodelas", uma grande área que ia desde o rio Carinhanha (na fronteira com Minas Gerais) até aproximadamente a foz do rio Moxotó 5 , estiveram congregados dezenas de aldeamentos missioneiros e as mais variadas etnias indígenas.

No entanto, a criação de gado, como especificidade econômica, contribuiu decisivamente às mudanças territoriais e urbanas nas margens e afluentes do rio em questão. Pedro Taques de Almeida, em carta de 20 de março de 1700, classificou-o como o rio dos currais ${ }^{6}$. Antonil calculou para as margens baianas 500 currais, "(...) E na banda da parte de Pernambuco, é certo que são mais (...)", alcançando um total de 8007. Desde o termo da vila de Penedo (AL) até a divisa das capitanias de Pernambuco e Bahia com Minas Gerais, inúmeros currais, pousos e fazendas de criar se estabeleceram, articulando o mercado interno de abastecimento de carne e couro aos principais núcleos urbanos litorâneos (São Luís, Olinda, Recife e Salvador) e arraiais de mineração. O paulatino povoamento do território, estimulado pelo movimento do gado e fortalecido pelo desenvolvimento de caminhos terrestres e fluviais em cooperação com a diversidade racial (índios, africanos e portugueses), formulou uma paisagem sui generis, amalgamada por tais "encontros culturais" 8 .

Para fins de análise, fracionamos este artigo em três partes. Na primeira consideraremos, em linhas gerais, a economia da pecuária e seus agentes 
(fazendeiros, curraleiros e procuradores) como leit motiv para a urbanização e estruturação da paisagem material elaborada no vale do rio São Francisco. Em seguida, por meio de cartografias coloniais (obtidas em bibliotecas virtuais nacionais e internacionais ${ }^{9}$ ) e mapas por nós produzidos, tentaremos dimensionar as transformações territoriais das capitanias da Bahia e Pernambuco, tendo como aporte principal o desenvolvimento de caminhos de condução ao interior. Por último, na terceira parte, exporemos os motivos políticos, sociais e econômicos considerados pelas autoridades civis e eclesiásticas para a formação da respectiva rede urbana do São Francisco.

É importante mencionar que, para as conceituações aqui propostas acerca da paisagem e rede urbana, nos pautamos nas definições de Milton Santos no que se refere a "rugosidades", "paisagem" e "rede". Para ele, as "rugosidades" são um conjunto de formas que, num dado momento, exprimem as heranças que representam as sucessivas relações localizadas entre o homem e a natureza ${ }^{10}$. Nelas convivem subsistemas técnicos de diferentes épocas e não podem ser apenas encarados como heranças físico-territoriais, mas também heranças socioterritoriais ou sociogeográficas ${ }^{1}$. Quanto à paisagem, Santos acrescenta que se trata de uma espécie de palimpsesto onde, mediante acumulações e substituições, a ação de diferentes gerações se superpõe ${ }^{12}$. Na mesma linha desse geógrafo, a historiadora medievalista portuguesa Amélia Aguiar Andrade, opina que a paisagem pode ser encarada como capaz de revelar a sociedade que a moldou e de exprimir as tensões entre os jogos das forças naturais - determinantes na escolha do sítio - e da ação humana, apresentando, dessa maneira, identidade própria, distinta de outras paisagens oriundas de outros encontros culturais ${ }^{13}$. Acerca da definição do que seja "rede" Santos nos diz:

As redes são formadas por troços, instalados em diversos momentos, diferentemente datados, muitos dos quais já não estão presentes na configuração ałual e cuja substituição no território também se deu em momento diverso. Mas essa sucessão não é aleatória. Cada movimento se opera na data adequada, isto é, quando o movimento social exige uma mudança morfológica e técnica. A reconstituição dessa história é, pois, complexa, mas igualmente ela é fundamental, se queremos entender como uma totalidade a evolução de um lugar ${ }^{14}$.

Reses, currais e curraleiros

Capistrano de Abreu, em sua obra Capítulos de História colonial, teceu reflexões sobre o papel da pecuária desenvolvida no grande curso do rio São Francisco. Chamou a atenção para o fluxo desenvolvido pelo gado que devassou áreas de Sergipe até aportar na margem direita do "Velho Chico"15. Tangidas da costa em direção ao rio, as reses encontrariam boas pastagens, água e sal tão necessários naqueles áridos sertões. Sérgio Buarque de Holanda apontou duas qualidades fundamentais à criação de gado e o consequente povoamento da área: "o relevo formado por peneplanícies e os barreiros salinos encontrados, as mais das vezes, ao longo do médio São Francisco"16. Considerada por Caio Prado Jr. como
9. Foram consultados os sítios das bibliotecas nacionais do Brasil, Portugal e Espanha e do Arquivo Nacional dos Países Baixos.

10. Ver Milton Santos (2009, p. 103).

11. Ver Milton Santos (2009, p. 43-44).

12. Ver Milton Santos (2009, p. 104).

13. Ver Amélia Aguiar Andrade (2003, p. 9).

14. Cf. Milton Santos (2009, p. 263).

15. Ver Capistrano de Abreu (2000, p. 151).

16. Cf. Sérgio Buarque de Holanda (1960, p. 221). 
17. Ver Caio Prado Junior (2000, p. 41-46).

18. Ver Manuel Correia de Andrade (1979).

19. Ver João Justiniano da Fonseca (1996, p. 25).

20. Ver Jacionira Coelho Silva (2003, p. 105).

21. Ver Jacionira Coelho Silva (2003, p. 106).

22. Cf. Ernesto Ennes (1938, p. 370).

23. Cf. AHU_ACL_CU_009, Cx. 33, D. 3343. Por questões de método de pesquisa, decidimos inserir neste ensaio a grafia encontrada nos documentos setecentistas.

24. Ver João Justiniano da Fonseca (1996, p. 25). uma "atividade acessória" à monocultura açucareira 17, a pecuária do Nordeste colonial, se assim o pudermos denominar, foi determinada pela necessidade de prover a força necessária aos trabalhos nos engenhos e alimentação da população litorânea ${ }^{18}$.

Para João Justiniano da Fonseca, a colonização e a progressiva ascensão populacional de moradores não indígenas ocorreram a partir de meados do século $\mathrm{XVII}$, quando foram solicitadas as primeiras datas de sesmarias localizadas no médio curso do rio, para criar gados soltos, extensivamente ${ }^{19}$. Os requerentes faziam parte da família dos Dias d'Ávila, conhecidos como a Casa da Torre. E, por isso, a criação dos primeiros currais e fazendas de gado foram estimulados, na maioria dos casos, por esse morgado e seus associados.

Apesar da legitimidade dos Dias d'Ávila e seus sócios em expandir seus imensos latifúndios e fundar currais nos sertões das capitanias da Bahia e Pernambuco, não foram os primeiros a povoar aqueles rincões. Segundo Jacionira Coelho Silva, antes dos rendeiros da Casa da Torre chegar ao serrão sanfranciscano, a ocupação da região já havia sido iniciada por André Rocha Dantas, que situou algumas fazendas de gado no São Francisco ${ }^{20}$. Em um mapa atribuído ao cartógrafo George Marcgraaf, datado de meados do século XVII, identificamos um curral "edificado" por Simão Ferreira. Ao sul, nas proximidades do que seria a capitania de Minas Gerais, situava-se o domínio de Antônio Guedes de Brito, que obtivera mais de 160 léguas de terras com testada no rio São Francisco, fracionando os sertões da Bahia e Pernambuco entre este e a Casa da Torre ${ }^{21}$.

Os currais e fazendas da Casa da Torre foram implantados seguindo a direção Oeste da Bahia. Não se limitaram às margens do grande rio, ao contrário, seguindo os seus afluentes expandiram-se para os sertões do Piauí, Rio Grande do Norte e Paraíba. Já no final do século XVII, o padre Miguel de Carvalho identificou no sertão piauiense "129 fazendas de gados, em que morão 441 pessoas entre brancos, negros, hindios [sic.], mullatos, e mestiços"22. A ampliação do número de fazendas e currais só foi possível graças aos procuradores e sócios da Torre, como Domingos Afonso Mafrense, Francisco Barboza Leão, Bernardo Pereira Gago e Francisco de Souza Fagundes ${ }^{23}$ que se dispuseram a "florescer" e povoar as sesmarias adquiridas, antes que se tornassem devolutas. Tal rede de relações fortaleceu o poder hegemônico da Casa da Torre em diversos sertões, especialmente no que no que diz respeito às questões de cunho jurídico, administrativo, religioso e econômico, levando Fonseca a qualificar aqueles imensos domínios como um "principado" 24. Com efeito, o jesuíta Antonil assinalou, para o início dos Setecentos, a dimensão fundiária e o quantitativo do gado criado nos currais da Casa da Torre:

Sendo o sertão da Bahia tão dilatado, como temos referido, quase todo pertencente a duas das principais famílias da mesma cidade, que são a da Torre, e a do defunto mestre de campo Antônio Guedes de Brito. Porque a casa da Torre tem duzentas e sessenta léguas pelo rio de São Francisco, acima à mão direita, indo para o Sul, e indo do dito rio para o norte chega a oitenta léguas (...). E, assim como há currais no território da Bahia e de Pernambuco, e de outras capitanias, de duzentas, trezentas, quatrocentas, quinhentas, oitocentas e mil ca- 
beças, assim a fazenda a quem pertencem tantos currais que chegam a ter seis mil, oito mil, dez mil, quinze mil e mais de vinte mil cabeças de gado, donde se tiram cada ano muitas boiadas $(\ldots)^{25}$.

Os "regentes" da Torre estavam localizados em seu "castelo" cerca de 14 léguas ao Norte da cidade de Salvador. A representatividade deles no sistema colonial tornara-se evidente. Assim percebemos ao analisar diversos mapas da época, em que os cartógrafos portugueses e/ou estrangeiros se preocuparam em locar com precisão a "fortificação" dos d'Ávila em suas cartas geográficas ${ }^{26}$. Contudo, a colonização e o respectivo povoamento de suas terras ocorreram por terceiros, mediante arrendamentos, o que criou uma trama de dependências clientelares e interesses entre o régulo e os seus foreiros ou procuradores.

Isso fez com que os assentamentos humanos no final do século XVII, tanto no curso sanfranciscano como em diversas partes do interior nordestino, tornassem pontos dispersos léguas e léguas uns dos outros salpicando a região, deixando muitos habitantes isolados e sem perspectiva de crescimento econômico, pois em pequenas roças produziram o necessário à sua subsistência ${ }^{27}$. Por volta de 1697, o carmelita frei Nicolao de São Joseph havia sido enviado pelo arcebispo da Bahia, dom João Franco de Oliveira, para verificar o progresso espiritual dos sertões de sua jurisdição. Ao questionar sobre a carência de capelas e igrejas matrizes naquelas paragens, justificaram os moradores ao religioso:

E preguntandolhes eu porq' não fazião Igreja e substentavão Padres q' thes desse missão responderão me q' Leonor Pereira Marinho [matriarca da Casa da Torre] hera senhora da mayor parte do sertão e q' não queria q' se fizesse lgrejas, e o mesmo dizia Antonio Guedes de Brito q' he senhor de mais de trezentas legoas emtre [sic.] o sertão e o Rio de São Francisco (...) como tambem Domingos Affonso (...) e se tem senhoreado de mais terras do que aquellas $q^{\prime}$ derão em Sismarias e $q^{\prime}$ não havia [h]oje mais terras descubertas e povoadas hera por culpa dos dittos senhores porq' asim como alguém descobre alguõ sitio e o quer povoar por thes ter custado a vida e despendio da sua fazenda em despossar o gentio e aldeallo e pollo no grêmio da lgreja, dizem os dittos senhores das terras $q^{\prime}$ the andem pagar renda ou quando não q' despejem porq' querem meter os seus gados nelle, e desta sorte se tinhão feitos senhores de mais terras do q' aquelles q' se tinhão dado em Sismaria... ${ }^{28}$.

A posse das terras pelos rendeiros da Torre e outros curraleiros foi marcada, muitas vezes, por intensos conflitos com os índios da região; com missionários detentores da administração temporal e espiritual dos aldeamentos missioneiros fundados sob aprovação real e com outros fazendeiros contrários aos objetivos do clã. Conforme mencionou o pe. Serafim Leite, o potentado dos d'Ávila deveria, segundo documentos emitidos pela Coroa portuguesa, reservar terras bastante para o sustento dos neófitos. Em vez de auxílio, fomentavam e moviam planos contra os religiosos que ousassem solicitar uma pequena fatia de terra (geralmente uma légua em quadra) de seus latifúndios ${ }^{29}$.

capuchinho Martinho de Nantes foi testemunha ocular desses conflitos no médio rio São Francisco. Percebeu, por volta de 1672, que Portugal apoiava a
25. Cf. André João Antonil (1982, p. 96).

26. Podemos elencar como exemplos de cartas geográficas: MAPA da Comarca da Babia de Todos os Santos sua divisão desde o rio Jiquiriça athé o rio Real pela parte Norte; D'ANVILLE, Jean-Baptiste Bourguignon. Carte qui répresente la partie meridionale du Brésil et du Peru, le Chili septentrional et le Paraguay (...); VILHENA, Luis dos Santos. Planta geografica do que se tem melhor averiguado nas Commarcas da Babia (...); "CARTE geografica del Bresil (1740)". A visualização dessas cartas está disponível no sítio da Fundação da Biblioteca Nacional do Rio de Janeiro.

27. Ver Damião Esdras Arraes $(2012$, p. 100).

28. Cf. AHU_ACL_CU_016, Cx.1, D. 4.

29. Ver Pe. Serafim Leite (1938, p. 300). 
30. Cf. Martinho de Nantes (1979, p. 60, 61).

31. Ver Marcos Galindo (2011, p. 168).

32. Cf. AHU_ACL_CU_015, Cx. 18, D.1771.

33. Cf. Pe. Serafim Leite (1938, p. 307). Em estudo sobre a Comarca de Itapicurú, Monica Dantas (2007, p. 50 ) indica que a aldeia de Natuba, que viria a ser a vila de Soure em 1758 , nunca chegou a desfrutar da área que lhe foi atribuida. O então "dono das terras", Gaspar Carvalho da Cunha, jamais concedeu desfazer-se daquela fatia de terra em prol da subsistência indígena. dilatação das terras da Casa da Torre por intermédio de provisões que contemplavam a expansão dos seus currais. Após insistentes pedidos de ajuda às autoridades governamentais e eclesiásticas, Nantes foi visto como "um inimigo e não como um missionário, visto que me opunha ao bem do Estado e às ordens, que o rei havia dado, para povoar as terras do rio para a subsistência das cidades da Bahia e Pernambuco" 30 .

Oaumento de sesmarias devolutas e das injustiças praticadas pelos régulos da Torre e seus procuradores fizeram com que El Rei - a partir da última década do século XVII - homologasse sanções legislativas com intuito de conter o crescente poder dos "mandatários" dos sertões da Bahia e de Pernambuco. Passa o poder real a orientar uma política não só de restrição às grandes glebas de terra, mas de coerção de privilégios, retraindo a autoridade do morgado e distribuindo mais equitativamente as novas possessões de terras ${ }^{31}$. A Carta Régia de 20 de janeiro de 1699 buscou remediar a evidente dispersão na qual viviam os habitantes das zonas interiorizadas do Nordeste e as irregularidades fundiárias, pois o território estava "dado a duas ou três pessoas particulares que cultivão as terras que podem [,] deichando [sic.] as mais devolutas sem consentirem que pessoa alguma as povoe salvo q. ${ }^{\mathrm{m}}$ a sua vista as descobrir defender e thes pagar dizimo de foro por cada Citio cada hum anno"32. Prosseguindo a leitura da Carta Régia, notamos que Portugal estabeleceu o direito de denunciar terras devolutas, e aqueles que assim agissem poderiam solicitar aos respectivos governos uma sesmaria de três léguas de comprido e uma de largo, em observância às Ordenações do Reino.

Já em 23 de novembro de 1700, El Rey emitiu um alvará em forma de lei em que supostamente favorecia o sustento dos missionários e dos índios convertidos ao catolicismo. A determinação régia reconhecia...

(...) ser justo se dê toda a providência necessária à sustentação para os Índios e Missionários, que assistem nos dilatados sertões deste Estado do Brasil, sobre que se tem passado repetidas ordens, e se não executam por repugnância dos donatários e sesmeiros, que possuem as ditas terras dos mesmos sertões, hei por bem e mando que a cada missão se dê uma légua de terra em quadra para sustentação dos índios e Missionários ${ }^{33}$.

Analisando um conjunto de cartas de doação de sesmarias, ofertadas entre 1699 - 1750, notaremos que o esforço da Coroa portuguesa - visando minimizar a autoridade dos grandes fazendeiros e distribuir igualmente as terras alcançou consideráveis índices. E, por esse motivo, a Casa da Torre e seus sócios iniciaram um longo expediente judicial de restituição das sesmarias, junto às instituições competentes locadas em Salvador e em Lisboa. Alegavam a necessidade das terras por motivos de antiguidade de posse, os esforços em conquistar e povoar os sertões sem patrocínio real e por ter travado guerras contra o gentio bravo, reduzindo-os em aldeamentos missioneiros a beneficiar a propagação da fé católica.

A coerção régia, que atingia diretamente os interesses da Casa da Torre e seus sócios, atraiu um contingente às margens do Rio São Francisco e a outros lugares, para fixarem residência de facto. A sociedade formada por portugueses 
(migrados do Minho, Douro e Açores), índios, africanos e mestiços esteve congregada em sólidas povoações. Com efeito, a Coroa lusa procurou reunir "a gente dispersa pelos campos" para submetê-la a seu controle religioso, fiscal, políitico e administrativo ${ }^{34}$ por meio da oficialização de povoações aos títulos de freguesia, "julgado" e vila. Entretanto, antes da ascensão da rede urbana estruturada no vale sanfraciscano, aquela ribeira e os sertões da Bahia e Pernambuco foram "irrigados" por uma teia de caminhos que conectavam distintas localidades da colônia entre si, moldando o território e configurando a paisagem ribeirinha.

rio São Francisco e seus caminhos

Devido às investidas de conhecimento do território interiorano do Nordeste, iniciadas já no século XVI e intensificadas nos Seiscentos, algumas "marcas" - trilhas e rotas - foram deixadas na região pelos colonizadores. Muitas delas eram reutilizações de antigos caminhos elaborados pelos indígenas locais, sendo útil destacar a ativa participação destes na transformação do hinterland das capitanias da Bahia e Pernambuco. Foi o caso do índio catequizado, Francisco Dias Mataroa, capitão-mor dos Porcazes e morador do Sertão de Rodelas, que auxiliou, em 1695, D. João de Alencastro, Governo Geral do Estado do Brasil, a desenvolver o caminho terrestre que uniu São Luís do Maranhão à cidade de Salvador ${ }^{35}$. A Coroa portuguesa e seus funcionários locados na colônia souberam utilizar esses encontros para moldar os sertões dos seus domínios, em acordo às suas ambições geopolíiticas.

No entanto, o desenvolvimento de estradas propriamente ditas pelos interiores baiano e pernambucano ocorreu graças à pecuária e aos percursos criados pelo gado. As vias ensejavam o conhecimento do território, diminuição do isolamento em que se encontravam os moradores da área, aumento do comércio, controle fiscal e administrativo por parte das câmaras das vilas e lucro ao cofre da Fazenda Real, através da coleta dos dízimos ${ }^{36}$. Nos tempos primeiros de ocupação dos sertões, tais vias eram "mal definidas, perceptíveis só aos olhos dos tupis" ${ }^{37}$. Eram caminhos originados por técnica rudimentar, feitos "tanto de enchada [sic.], como foice e machado" 38 .

Muitas rotas seguiam o curso dos principais rios. No Ceará, a estrada geral do Jaguaribe esteve marginal ao percurso elaborado pelo rio de mesmo nome, e ligou o litoral cearense ao rio São Francisco ${ }^{39}$. A estrada real do gado, caminho cuja elaboração fora articulada pela monarquia lusa, percorria o "serpentear" dos rios Itapicurú (MA) e Canindé (PI) ${ }^{40}$. Determinados caminhos tiveram como ponto de chegada o "Velho Chico" ou nele cruzavam, originando outras estradas, cujas conexões uniram os sertões ao litoral e às outras partes da Colônia.

A rede de relações efetuadas entre as distintas partes da Colônia alargouse com a descoberta das minas de ouro, ocorrida no final do século XVII. Um autor anônimo, contemporâneo à formação das catas de mineração, narrou a importância do caminho que margeava o São Francisco na interligação entre Bahia, Pernambuco e Maranhão com as minas. Tomadas as devidas coordenadas de tempo e espaço,
34. Ver Nestor Goulart Reis Filho (2000, p. 112).

35. Cf. AHU_ACL_CU_015, Cx. 18, D.1764

36. Ver Damião Esdras Arraes $(2012$, p. 100).

37. Cf. Carlos Studart Filho (1937, p. 15).

38. Cf. Barbosa Lima Sobrinho (1978, p. 48).

39. Ver Carlos Studart Filho (1937, p. 27).

40. Cf. AHU_ACL_CU_009, Cx. 9, D. 906. 
41. Cf. Informação... (1939, p. 173).

42. Cf. Capistrano de Abreu (2000, p. 151).

43. Raphael Bluteau define o verbete "coimbraan" como um "(...) Caminho Real, direyto, \& trilhado sem atalhos, nem rodeos (...)". Ver Raphael Bluteau (17121719, p. 365).

44. Apud José Alípio Goulart (1963, p. 16-26).

45. Ver Capistrano de Abreu (2000, p. 151-160).

46. Ver Frei Vicente Salvador (1982, p. 152). o isolamento e dispersão dos assentamentos humanos sertanejos minimizaram com a abertura do caminho:

Este caminho he geral p. ${ }^{a}$ todas as povoações da Bahia, Pern. ${ }^{c o}$, e Maranham, asim das da costa do Mar, como dos recôncavo, e sertões dos seus distritos, porque de todas as partes e povoações das $\mathrm{d} .{ }^{a}$ Capitanias há hoje caminhos, comonicação [sic], e trato p. ${ }^{a}$ os currais do rio de São Fran. ${ }^{c 0} 41$.

Capistrano de Abreu dissertou sobre dois polos de arremetida aos sertões da Bahia e de Pernambuco. Batizou o movimento liderado pelos baianos de "sertão de dentro"42, ou seja, partindo de Salvador, os sertanistas rumavam aos hinterlands margeando os principais rios, cujo objetivo seria encontrar o rio São Francisco. Tais fluxos criaram rotas conectando o Recôncavo da Bahia às margens médias sanfranciscanas, e, após o descoberto aurífero, uniria aquela região às Minas Gerais. $\bigcirc$ roteiro escrito pelo fazendeiro e sócio da Casa da Torre, Domingos Afonso Mafrense (depois alcunhado de Sertão) endossa o crescimento da comunicação entre o rio São Francisco com a Bahia, Piauí, Maranhão, Pernambuco e Minas Gerais. $\bigcirc$ rio foi de fato um eixo condutor, baliza nos intentos de devassar, conhecer, povoar e dilatar as fronteiras do Brasil Colônia:

Da cidade da Bahia ia uma estrada coimbrã ${ }^{43}$ pela Jacobina até o rio São Francisco, numa extensão de aproximadamente 130 léguas, pela qual vinham a maior parte dos gados que se criavam naqueles sertões, para o sustento da cidade e seus arrabaldes. Dalí seguia para o Norte, sempre beira-rio, umas 20 léguas, ao cabo das quais começava uma estrada, também coimbrã por onde vinham os gados das povoaçães novas do Callindê, Piagohy e Parnaíba. Da estrada do rio São Francisco aos currais de gado do primeiro povoado distavam umas 40 léguas e deste último, para o lado do Maranhão, 30 léguas; daqui até a cidade do Maranhão iam umas 70, havendo também um caminho mandado descobrir por $\mathrm{D}$. João de Lencastro, mas todo ele despovoado, devido a gentio bravo que por ali havia. Também da mesma povoação partia uma estrada para - Ceará, Rio Grande, Paraíba e Pernambuco, por onde poderiam ir socorros sempre que fosse preciso, em carros e cavalos, porque por todas aquelas paragens havia muitos currais de gados e farinhas para o sustento desses comboios, salvo nas 70 léguas iá indicadas. (...) Havia um outro caminho da Bahia para as minas de ouro, que se abria por onde chamavam Perogoassu, que era mais perto e ia sair ao rio de São Francisco perto da Barra do Rio das Velhas, mas também era despovoado. (...) Os caminhos por terra eram bons, conduzindo-se por eles os gados do rio Grande de S. Francisco, para o sustento dos fabricadores das minas de ouro... ${ }^{44}$.

Ainda no dizer de Abreu, ao contrário dos baianos que se deslocaram para os rincões de sua capitania, os pernambucanos atuaram como "sentinelas" das áreas costeiras e das férteis plantações de açúcar, e por esse motivo, "pouco" se interessaram pelo território sertanejo e pelo que a região poderia oferecer aos seus cofres privados. $\bigcirc$ historiador chamou tal incursão de "sertão de fora"45, conceito convergente à metáfora de frei Vicente de Salvador, em que o colonizador arranhou a costa como caranguejo ${ }^{46}$. Contudo, na contramão de Capistrano de Abreu, os historiadores pernambucanos Barbosa Lima Sobrinho e José Antônio Gonsalves de Mello Neto, tendo como base documentação manuscrita primária, perceberam que de Olinda e Recife partiram caminhos em direção contrária aos contornos da praia, acompanhando o curso dos rios Capibaribe e lpojuca, com destino às Minas Gerais 
e passando pelo rio São Francisco ${ }^{47}$. Lima Sobrinho e Gonçalves de Mello dimensionaram a atenção dada por Pernambuco em controlar e fiscalizar os confins da capitania, não restringindo sua administração à pequena parcela guarnecida por lavouras e engenhos de açúcar ${ }^{48}$.

$\bigcirc$ percurso pelo rio Capibaribe é o mais antigo. Partindo do litoral pernambucano, a freguesia de Santo Antão era o primeiro ponto de parada e, após passar algumas fazendas de gado e dezenas de pousos, os colonos aportavam na freguesia de Ararobá, "(...) toda cultivada de moradores..." 49. Desta freguesia a rota se prolongava até a paróquia de Cabrobó, a mais dilatada de todo o sertão pernambucano, cuja extensão ultrapassou as 400 léguas $^{50}$. Por fim, o caminho encontrava o rio São Francisco, donde se podia chegar à capitania das minas de ouro tanto por terra quando por via fluvial. Nesse último caso, o viajante poderia ser auxiliado por índio catequizado, residente em algum dos aldeamentos missioneiros existentes ali. Em Cabrobó, outro caminho cruzava a povoação, dessa vez vindo da foz do São Francisco passando pela vila de Penedo. Essa via fora registrada no mapa do cartógrafo holandês Johannes Vingboons, datado de 1665 (Figura 1).
47. Ver Barbosa Lima Sobrinho (1978, p. 41-49) e José Antônio Gonsalves de Mello Neto (1966, p. 07 - 11).

48. Outros caminhos que partiam do litoral da capitania de Pernambuco foram transcritos e mapeados por Carlos Studart Filho (1937, p. 15-25) e Manuel Correia de Andrade (1979). Essas rotas conectavam Olinda, Recife e a cidade da Paraíba com os sertões do Piauí, Ceará, Paraíba e Rio Grande do Norte, equacionando, portanto, uma dinâmica de caminhos pouco dissertada nos estudos da historiografia brasileira.

49. Cf. Barbosa Lima Sobrinho (1978, p. 48).

50. Cf. AHU_ACL_CU_015, Cx. 17, D. 1732.

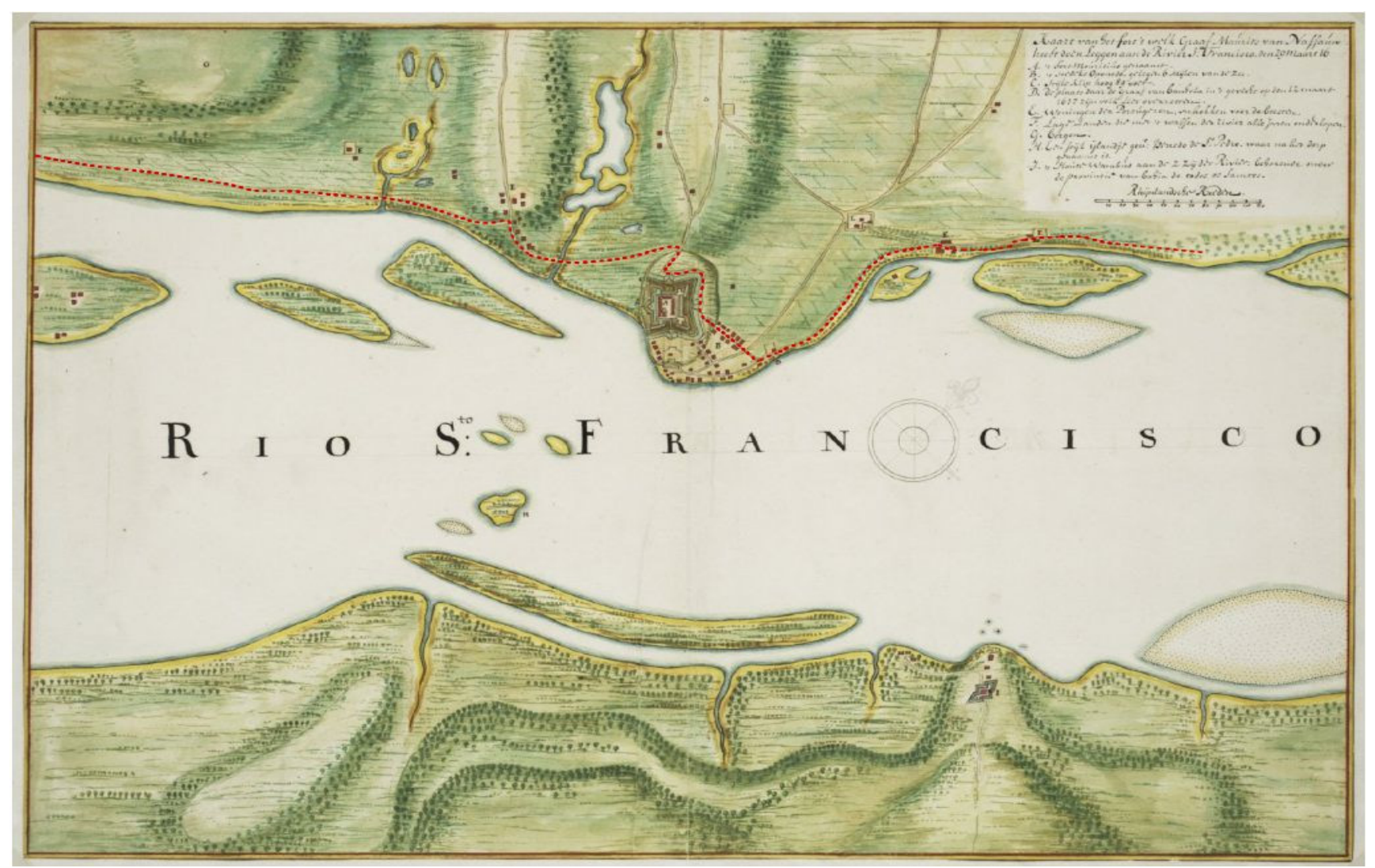

Figura 1 - Johannes Vingboons. Kaart van het fort't week graaf Mauritis Van Nassauw heeft doen leggen aan de rivier St. Francisco den 29 maart 16. Plattegrand van fort Mauritis bii Rio Santo Francisco, Brazilië. Acervo do Nationaal Archief, Haia. Em vermelho, linha pontilhada, o caminho que ladeava o rio São Francisco, desde sua foz até a freguesia de Cabrobó, donde se conectava com uma rota de condução à capitania das Minas Gerais. 
51. Ver André João Antonil (1982, p. 97).

52. As capitanias do Norte (termo utilizado nos Setecentos) envolveram geograficamente o território dos atuais estados do Ceará, Rio Grande do Norte, Paraíba, Pernambuco, Alagoas, Sergipe e Bahia.

53. Por exemplo, nas Constituições Primeiras do Arcebispado da Babia (redigidas em 1707 e publicadas no ano de 1719) em seu livro Quarto, título 687 recomendou-se que as igrejas matrizes " $(\ldots)$ se devem fundar, e edificar e lugares decentes, e acommodados que mandamos (...) que se edifique em sitio alto, e lugar decente, livre da humidade, e desviados, quando for possivel de lugares immundos, e sordidos (...)". Cf. Sebastião Monteiro da Vide (2011. p. 252).A Carta Régia que instituiu a vila cearense de Icó ordenou sua implantação em "(...) sítio que parecer mais saudável e com provimento de água (...)".Citada por Paulo F. Santos (2001, p. 51).

54. Ver Cláudia Damasceno Fonseca (2011).
As conexões viárias, aqui resumidamente expostas, foram por nós georeferenciadas de acordo com o mapa da Figura 2. Com efeito, ao rio São Francisco convergiram importantes caminhos, tirando do cotidiano a morosa vida daqueles que se arriscavam a habitar os sertões da Bahia e Pernambuco.

Ao longo desses caminhos, uma variedade de embriões de povoamento, de diferentes níveis e perfis, era fixada: pousos se estabeleciam Igeralmente para a engorda da boiada e acomodação dos vaqueiros, passadores e tangedores), fazendas e capelas eram erguidas, bem como paróquias, "julgados" e vilas eram oficializados. Da capital baiana até a margem do médio rio São Francisco, sabemos que, entre 1675 - 1727 , estiveram interligadas por via terrestre as vilas de Cachoeira, Jacobina e Água Fria; as missões do Sahy e Juazeiro e a feira de gado de Capuame ${ }^{51}$. A maioria das povoações - oficializadas ou não pela Coroa - estava interligada no caminho aberto desde a foz atlântica do São Francisco até a fronteira com a capitania das Minas Gerais, na altura do julgado de Carinhanha. Os núcleos urbanos e a respectiva rede por eles estruturada serão abordados no próximo item deste artigo. As funções territorial e urbana desses caminhos devem ser destacadas, pois a interferência destas na região marginal ao "Velho Chico" é essencial para o entendimento de paisagem material e divisão social e territorial do trabalho equacionadas naqueles rincões.

\section{Os assentamentos humanos do rio São Francisco}

Boiadas, pousos, fazendas e caminhos entram, portanto, no quebracabeças da urbanização tanto do vale sanfranciscano como de todo o interior das capitanias do Norte ${ }^{52}$. São eles incógnitas fundamentais para compreender as ulteriores etapas de povoamento e congregação humana em núcleos urbanos oficializados pela Coroa portuguesa, dentro das categorias de freguesia ou paróquia, julgado e vila. Contudo, as povoações que almejassem tais títulos honoríficos deveriam responder a um rígido índex de necessidades imposto pela Metrópole, pela lgreja Católica e por oficiais régios, que, grosso modo, seriam: não estar localizados em sítios impróprios e ermos ${ }^{53}$; haver transação comercial na povoação; qualidade dos moradores (se existiam "homens - bons" na localidade); quantidade de irmandades leigas; aspectos materiais do templo católico que solicitava o status freguesia, entre outros.

De maneira geral, os condicionantes citados eram os mais básicos para se requerer uma nova categoria urbana. Todavia, estudos mais recentes, como o de Cláudia Damasceno Fonseca, indicam outros fatores ligados a questões de poder e controle territorial, como mais expressivos às promoções urbanas e à constituição da teia de aglomerados no Brasil dos Setecentos ${ }^{54}$. É interessante notar que, para o espaço geográfico aqui contemplado, ainda apontamos, como essencial à formação de sua respectiva rede urbana, a busca incessante dos moradores por justiça diante das criminalidades e fraudes fundiárias muito 


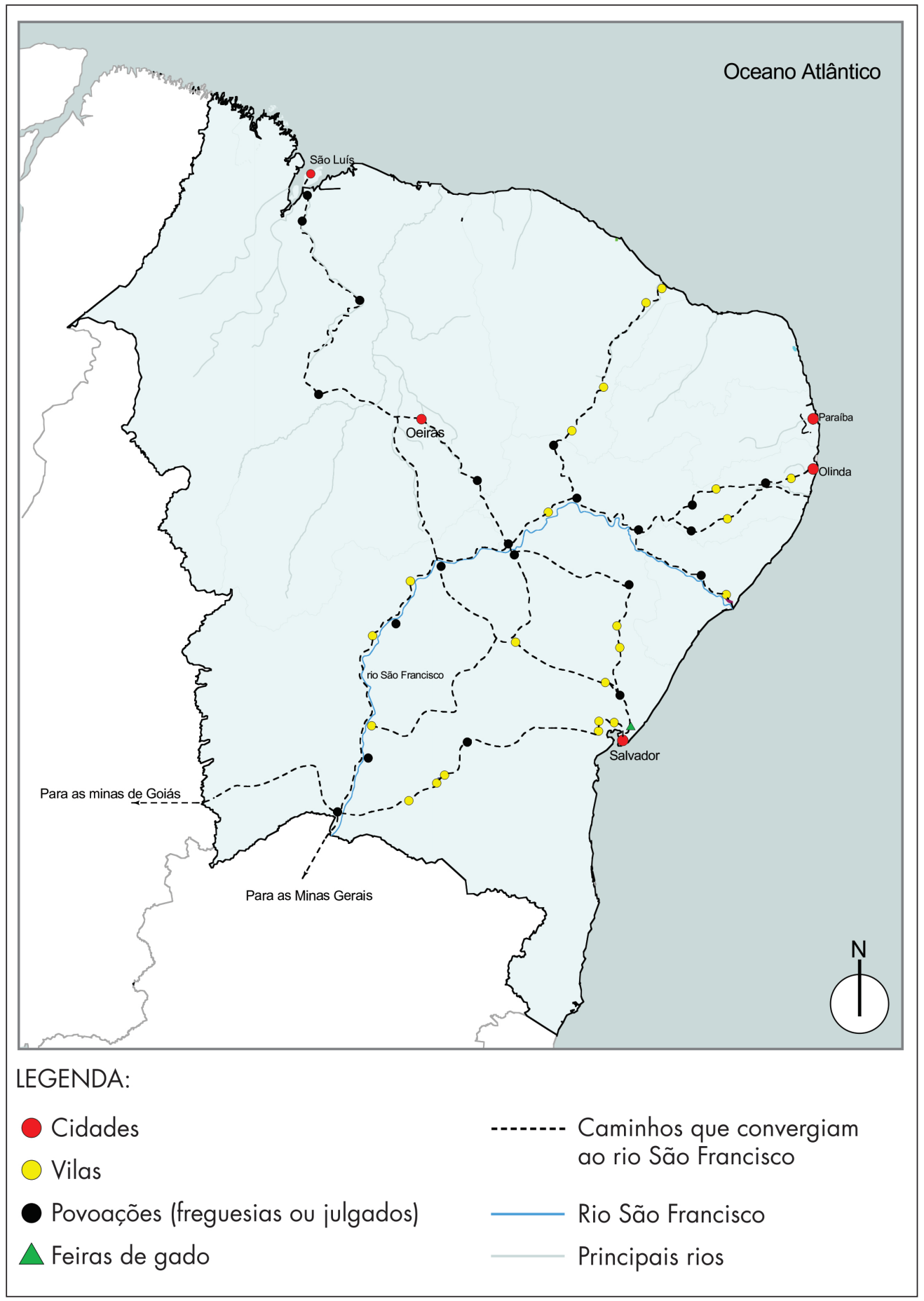

Figura 2 - Caminhos terrestres criados nos tempos coloniais e marginais ao rio São Francisco ou a ele convergentes. Desenho do autor, baseado em manuscritos do Projeto Resgate Barão do Rio Branco; André João Antonil (1982, p. 97); Ernesto Ennes (1938, p. 371); Barbosa Lima Sobrinho (1978, p. 48-49); Carlos Studart Filho (1937, p. 27); Informação sobre as minas..., (1935, p. 1731; José Alípio Goulart (1963, p. 16-26). 
55. Para nós, tanto a malha formada por freguesias quanto a elaborada por vilas e cidades são resultados de ações régias, portanto oficiais. No caso específico das freguesias, isso se deve ao Padroado, isto é, um pacto de benefício mútuo estabelecido entre a Igreja Católica e a Coroa lusa através de diversas bulas. Para Riolando Azzi (2008, p. 161-169), o Padroado seria o método do qual o governo português exerceria sua função de "protetor" da Igreja em seus domínios e propagador da fé católica aos milhares de gentios das conquistas. Apesar dos privilégios materiais concedidos pelo Rei ao Papa, essa relação significou a submissão da Igreja às decisões tomadas pela Coroa. Consequentemente, a instituição de paróquia, prelazia e/ou diocese passava pela aprovação real.

56. Ver Idéia de população... (1918, p. 60).

57. Cf. Informação geral... (1908, p. 385)

58. Ver Cristina Pompa (2011, p. 269). Ainda segundo Pompa, o termo "Tapuia" não é um etnônimo, e sim uma categoria colonial. O mundo "Tapuia" foi pensado, desde o princípio da colonização, em oposição ao mundo tupi. Idem (p. 269, nota de rodapé).

59. Ver Martinho de Nantes (1979, p.103).

60. Ver João Justiniano da Fonseca (1966, p.87).

61. Ver Martinho de Nantes (1979, p. 122).

62. Ver João Justiniano de Fonseca, 1996, p. 90). corriqueiras durante o período colonial. De fato, poder, controle territorial e fiscal e acesso à justiça moveram a Coroa, seus representantes diretos e as câmaras locais a equacionar, com diálogo e/ou embate, a estruturação da malha urbana e a hierarquia dos arraiais fundados na colônia.

Isso posto, as redes urbanas eclesiástica e civil, formadas e oficializadas pela Coroa portuguesa no curso do São Francisco, surgiram com a instituição da primeira paróquia ${ }^{55}$. Em 1636, foi criada a de Nossa Senhora do Rosário ${ }^{56}$, embrião do que viria a ser a vila de Penedo, localizada no atual estado de Alagoas. Paralelamente à oficialização dos núcleos urbanos, distribuiuse pela área dezenas de aldeamentos missioneiros governados, em sua maioria, por capuchinhos, jesuítas e franciscanos (Figura 3). As comunidades indígenas, além de serem alvo dos objetivos elementares de catequizar e domesticar o gentio para torná-los vassalos do rei e filhos de Igreja, assegurariam "(...) a defensa daquelle Certão, por terem muitas aldeyas domesticas, $q^{\prime}$ as defendão das entradas dos brabos..." ${ }^{17}$. Diz Cristina Pompa que os missionários foram agentes essenciais aos planos do governo, pois a evangelização previa a construção de uma barreira de aldeias de índios mansos e o controle da região utilizando aldeamentos de Tapuias pacificados ${ }^{58}$.

De fato, o Império português patrocinou a fundação de missões religiosas espalhadas em pontos nevrálgicos do território sanfranciscano. Em muitos desses lugares, o intenso litígio envolvendo a Casa da Torre, os Tapuias, os missionários, os curraleiros e as autoridades locais tornou-se comum. Por exemplo, desde a Passagem do Juazeiro (hoje cidade de Petrolina, PE) até a sede paroquial de Cabrobó, notamos, mediante o mapa da Figura 3, assentamentos de doutrinação indígena mais adensados entre si diante da característica dispersão observada nos sertões restantes. Ali ocorreram, conforme relatado por frei Martinho de Nantes em sua Relação, conflitos sociais cuja origem reporta-se a questões fundiárias e o uso dos neófitos em futuras guerras de conquistas $^{59}$.

A catequese no rio São Francisco foi iniciada, segundo João Justiniano da Fonseca, por volta de 1671, pelo capuchinho Francisco de Domfront ${ }^{60}$. Foram erguidas as reduções de Poquim, Aramurus, Rodelas, Iha das Vacas e Aracapábl $^{6}$. Os jesuítas chegaram ao território ribeirinho na década de oitenta dos Seiscentos, quando reuniram 3.900 almas, divididas em duas aldeias maiores e três menores: Rodelas, Acará, Arnipó, Caruru e Sorobabéb2. Os padres da Companhia de Jesus administraram suas aldeias até julho de 1696, quando foram expulsos pela Casa da Torre por não aceitar o uso dos índios aldeados em guerras e por solicitar sesmarias necessárias à plantação de pequenas roças para o sustento dos nativos. Após a expulsão dos barbadinhos franceses dos domínios de Portugal, ocorrida em 1701, devido a questões diplomáticas, as missões religiosas do São Francisco - locadas na jurisdição pernambucana - aumentaram, sendo listadas na Informação Geral da Capitania de Pernambuco de 1749: 


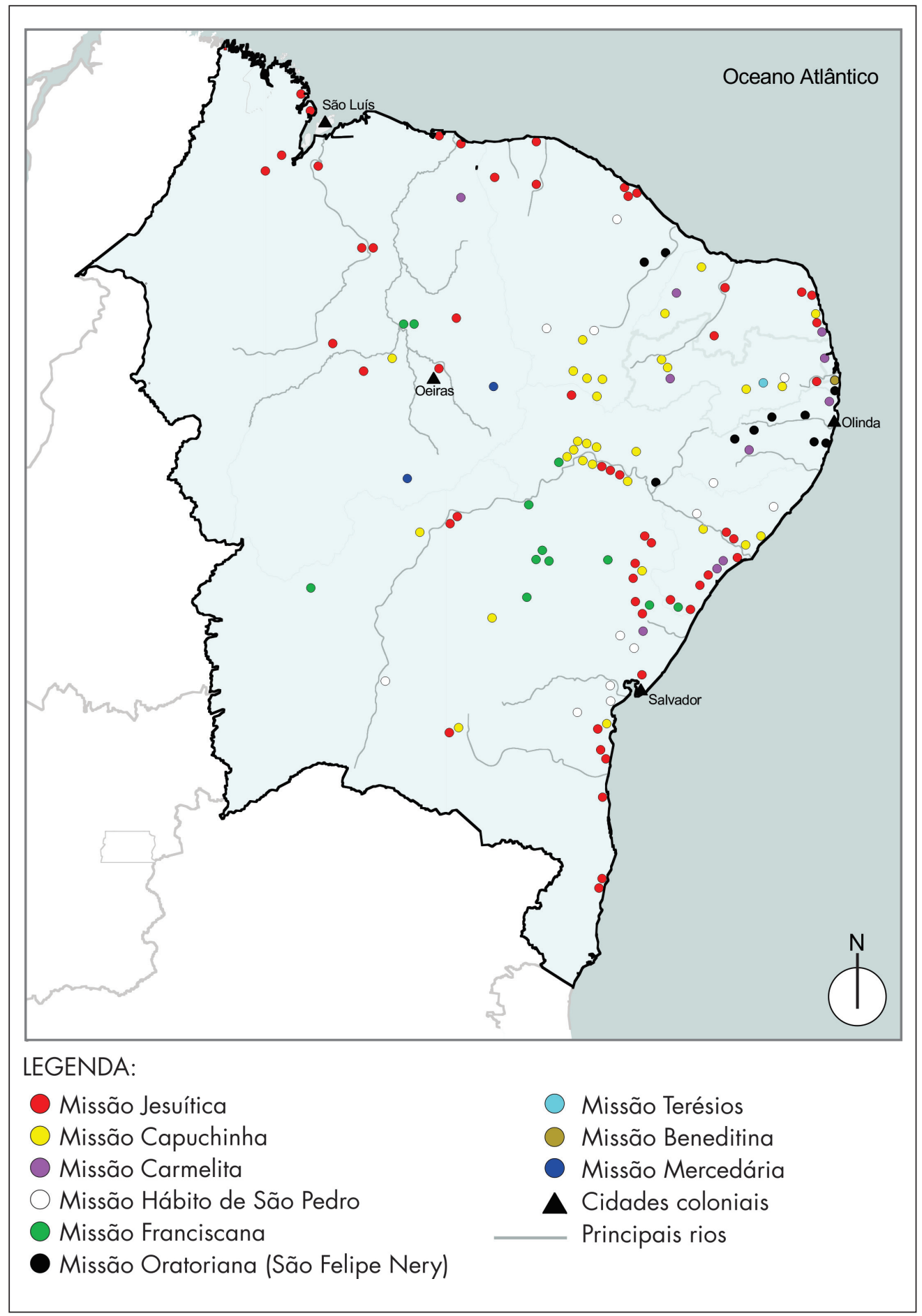

Figura 3 - Aldeamentos missioneiros no Nordeste fundados entre 1549 e 1822. Desenho do autor, baseado em manuscritos encontrados no Projeto Resgate Barão do Rio Branco; Capistrano de Abreu (2000, p. 194-197); João Pacheco de Oliveira (201 1, p. 690 -707); Informação geral... (1906, p. $419-4221$. 
63. Elaboração do autor segundo Informação Geral... (1906, p. 421 - 422).

64. Serafim Leite (1938, p. 301) menciona um frade franciscano, padre Agostinho, o qual assitindo em casa do Sargento mor e procurador da Casa da Torre, Antônio Gomes de Sá, era a favor da extradição dos jesuítas de suas missões implantadas no rio São Francisco.. João Justiano da Fonseca (1996, p. 109) relata que a matriarca do morgado, D. Leonor Marinho, declarava estar disposta em sustentar os religiosos nos aldeamentos erguidos em seus domnínio, desde que fossem ministrados por franciscanos.

65. Cf. AHU_ACL_CU_ BAHIA, Cx. 20, D. 3757 3772 .

\section{Tabela 1}

Missões religiosas no rio São Francisco locadas na banda da capitania de Pernambuco63

\begin{tabular}{|c|c|}
\hline MISSÃO RELIGIOSA & MISSIONÁRIO \\
\hline Missão Nova de S. Francisco & Franciscano \\
\hline Nossa Senhora do Ó & Franciscano \\
\hline Nossa Senhora de Belém & Capuchinho italiano \\
\hline Beato Serafim & Capuchinho italiano \\
\hline Nossa Senhora da Conceição do Pambú & Capuchinho italiano \\
\hline São Félix & Capuchinho italiano \\
\hline Aldeia de São Francisco, da ilha de Aracapá & Capuchinho italiano \\
\hline Santo Antônio, da ilha de Irapuá & Capuchinho italiano \\
\hline Nossa Senhora da Piedade & Franciscano \\
\hline Nossa Senhora do Pilar & Franciscano \\
\hline Nossa Senhora dos Remédios & Franciscano \\
\hline Aricobé & Franciscano \\
\hline Aldeia de Pão de Açúcar & Companhia de Jesus \\
\hline
\end{tabular}

É interessante destacar algumas evidências elencadas na tabela 1, cujas informações apontam, mesmo que indiretamente, ao tipo de urbanização e às relações de poder encerradas naquela banda do rio São Francisco. Percebe-se que tanto capuchinhos quanto franciscanos administraram $46 \%$ das missões religiosas, enquanto que somente $8 \%$ delas estiveram sob a tutela jesuítica. Os padres da Companhia de Jesus não eram bem aceitos pela Casa da Torre, haja vista a destruição de uma igreja e residências dos padres executadas por índios agregados à Torre. Enquanto isso, conforme nos expõem os dados da Informação Geral, franciscanos e capuchinhos governaram o mesmo número de missões - seis. Tal índice deve-se às estreitas relações entre os franciscanos e a Casa da Torre ${ }^{64}$. A ordem de São Francisco recebeu a administração das aldeias que haviam sido dos inacianos, porque atendiam os interesses e conveniências da Casa da Torre de alargar seus latifúndios e dispor os índios "domesticados" para futuras "guerras justas".

Na banda baiana, temos notícias, segundo o relatório do Desembargador Thomaz Roby de Barros Barreto dirigido a D. José I em 1758, de nove missões tuteladas pelos capuchinhos (Irapoá, Pambú, Vargem, Araxá, Rodelas, São Pedro, Vacapará, São Félix e Pacatuba) versus seis governadas pelos franciscanos (Unhunhu, Juazeiro, Pontal, Curral de Bois, Caripós e Sorobabé)|65. Os jesuítas, depois do envolvimento em diversos conluios, foram expulsos de seus aldeamentos sanfranciscanos, concentrando sua ação catequética nas reduções sertanejas de 
Saco dos Morcegos, Canabrava, Natuba e Gerúbo, sendo elas convertidas em vilas com a homologação do Diretório dos Índios e adquirindo as nomeações respectivamente de Mirandela, Pombal, Soure e Tomar do Gerú.

Os conflitos envolvendo os diversos agentes da colonização supracitados motivou a Coroa a vigiar esses acontecimentos. $\bigcirc$ que resultou na sanção das Cartas Régias de 20 de janeiro de 1699 e 23 de novembro de 1700, cujo teor indicava resoluções mais incisivas no território sertanejo, tais como uma política de restrição e coerção de privilégios aos grandes fazendeiros, de maneira que o poder deles minguasse com o decorrer dos anos.

A concretização desses ideais, iniciada no reinado de D. Pedro ll e com interessantes resultados na administração de D. José I auxiliado pelo marquês de Pombal, daria, como aconselhou o bispo de Pernambuco, D. Francisco de Lima, em reduzir "aquellas terraz [sic.] a Collonias, e Povoações, sendo este o meyo não só de se segurarem aquelles Certoens com estas defensas, mas tambem o de poder lucrar grandez conciniençias a fazenda de V. Mag. de nos dizimos que se podem tirar da cultura dellas..."67. A partir de 1636, o curso do rio São Francisco foi ladeado pela formação de uma rede urbana eclesiástica de freguesias e uma outra civil composta por arraiais com os status de julgado e/ou vila. Esse sistema urbano, em tese, viria a remediar os problemas sociais relacionados a jogos de poder, parcialidades administrativas e usurpação da justiça.

Num primeiro instante, abordaremos a malha paroquial, por se tratar, segundo estudo pioneiro de Murillo Marx, em um dos primeiros estágios evolutivos dos privilégios urbanos concedidos pela Coroa e Igreja Católica, umbilicalmente unidos por pactos de benefícios recíprocos ${ }^{68}$. $\bigcirc$ reconhecimento do Estado português, no que se refere à vida dos assentamentos humanos dispersos, se dava pela oficialização de uma ermida ao novo título de freguesia ou paróquia ${ }^{69}$. Com efeito, a primeira sede paroquial erguida na borda sanfranciscana fora a antes citada de Nossa Senhora do Rosário, criada em 1636. Nesse período, a capitania de Pernambuco e outras partes do atual Nordeste brasileiro estavam subjugadas aos holandeses. Por esse motivo, aludimos que a povoação recebera o status de paróquia como demonstração da Metrópole lusa em vedar a entrada dos flamengos aos sertões e a seus domínios pelo rio São Francisco. Sendo assim, aplica-se perfeitamente à freguesia de Nossa Senhora do Rosário a metáfora de a "chave do sertão" atribuída ao padre oratoriano João Duarte da Costa ${ }^{70}$.

À medida que as terras sertanejas eram colonizadas, aglomerações humanas progressivamente se desenvolviam, tendo como composição social nuclear um reduzido número de moradores, em geral formada pelo fazendeiro e seus agregados. Muitos deles eram procuradores ou feitores dos poderosos d'Ávila, que estimulavam o povoamento de suas terras na expectativa de as não tornar devolutas. Por isso, encontramos tais representantes distribuídos onde convinha aos interesses da Casa da Torre: além do vale do São Francisco, nas capitanias do Piauí e Paraíba e ribeira do riacho da Brígida. Em sua margem média, notadamente a mais beligerante, fora instituída outra freguesia e a mais dilatada de todas: Nossa
66. Ver Luiz dos Santos Vilhena (1802, p. 231)

67. Cf. Ernesto Ennes (1938, p. 349-350).

68. Ver Murillo Marx (1991, p. 18).

69. Ver Murillo Marx (1991, p. 18).

70. Ver Ebion Lima (1979, p. 69-118). 
71. Cf. Ernesto Ennes (1938, p. 353).

72. Cf. AHU_ACL_CU_009, Cx. 29, D. 2978.

73. Cf. Ernesto Ennes (1938, p. 355).

74. Ver Nestor Goulart Reis Filho (2000, p. 71).

75. Cf. AHU_ACL_CU_ BAHIA, Cx. 15, D. 2717.

76. Entre parêntesis o ano de fundação das paróquias.

77. Informações coletadas em <www.arquidiocesesalvador.org.br>, acesso em 26.04.2013.

78. Ver Murillo Marx (1991, p. 20-22).

79. A freguesia de Nossa Senhora do Ó do Porto da Folha fora oficializada no território da diocese de Pernambuco.

80. Ver Freguesias da Babia..., maço 5247.
Senhora da Conceição do Cabrobó, hoje uma pequena cidade de mesmo nome. Não se sabe ao certo a data de criação da paróquia de Cabrobó, todavia a sua precisa localização e a dimensão de seu território - "400 legoas cortado de varios rios"71 - são pistas fundamentais para se compreender a urbanização encerrada nos sertões das capitanias da Bahia, Pernambuco e Piauí.

Em 1697, Cabrobó fora fracionada em duas novas paróquias, uma delas fundada no conjunto de freguesias sanfranciscanas - São Francisco da Barra do Rio Grande do Sul. Tal povoação exercerá importante papel nas futuras conexões comerciais com as Minas Gerais, haja vista a sua proximidade com a capitania mineira. Atuaria como "sentinela" dos caminhos que margeavam o São Francisco, já que por ali comumente eram contrabandeados ouro em pó das lavras. Além do mais, a oficialização da freguesia da Barra seria um ótimo artifício para aumentar as rendas reais advindas dos dízimos e dos contratos das carnes e passagens dos rios. Também, as injustiças praticadas naqueles rincões, consideradas pela Coroa como um "mal"72, seriam remediadas com a criação de sólidos núcleos de

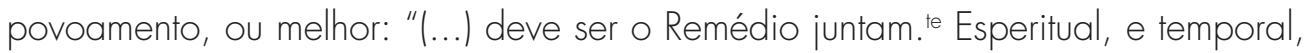
Esperitual p..$^{\circ}$ beneff. ${ }^{\circ}$ dos Parochos, e opperarios, e o temporal p. ${ }^{l}$ correcção, e castigo dos delictos" 173

A partir do reinado de $D$. Pedro Il e, principalmente, por intermédio da política expansionista de D. João $V$, as atividades urbanizadoras foram intensificadas ${ }^{74}$. $O$ resultado desse planejamento português pode ser visto por meio da criação de dezenas de freguesias estrategicamente distribuídas nos "Certoens" das capitanias do Norte. No que respeita ao rio São Francisco, o Arcebispado da Bahia e o Bispado de Pernambuco, sob a batuta real75, fundaram quatro novas freguesias em seu vale: Nossa Senhora do Ó do Porto da Folha (1714)7\%; Santo Antônio do Pambú (1714); Santo Antônio do Urubu de Cima (1718) e Santo Antônio do Urubu de Baixo (1718) (Figura 4). A oficialização dessas novas paróquias foi contemporânea à administração eclesiástica de D. Sebastião Monteiro da Vide, arcebispo da Bahia entre 1701 - $1722^{77}$ e organizador das Constituições Primeiras do Arcebispado da Bahia. Para Murillo Marx, essas normas pias estavam atentas à uniformidade dos ritos católicos propagados pela Contra Reforma, entre os quais o dever da lgreja e do Estado em amparar espiritualmente os moradores mediante sua congregação em freguesias ${ }^{78}$. Além das três sedes paroquiais erguidas na ribeira sanfranciscana, pertencentes ao Arcebispado da Bahia ${ }^{79}$, outras vinte freguesias, localizadas em distintas partes do sertão baiano, foram instituídas por Monteiro da Vide sob Alvará régio ${ }^{80}$.

Entre 1750 e 1777, recorte temporal que coincide com o reinado de D. José l e o apoio direto do conde de Oeiras (futuro marquês de Pombal), verificamos um salto numérico de novas freguesias formalizadas ao longo do rio São Francisco. Até onde sabemos, foram oito no total, implantadas nas bandas baiana e pernambucana: Santo Antônio do Pilão Arcado (1755); São José da Barra do Sento Sé (1755); Nossa Senhora da Saúde de Tacaratú (1761); Nossa Senhora da Assunção (1761); Santa Maria (1761); São João Batista do Sertão dos Rodelas 


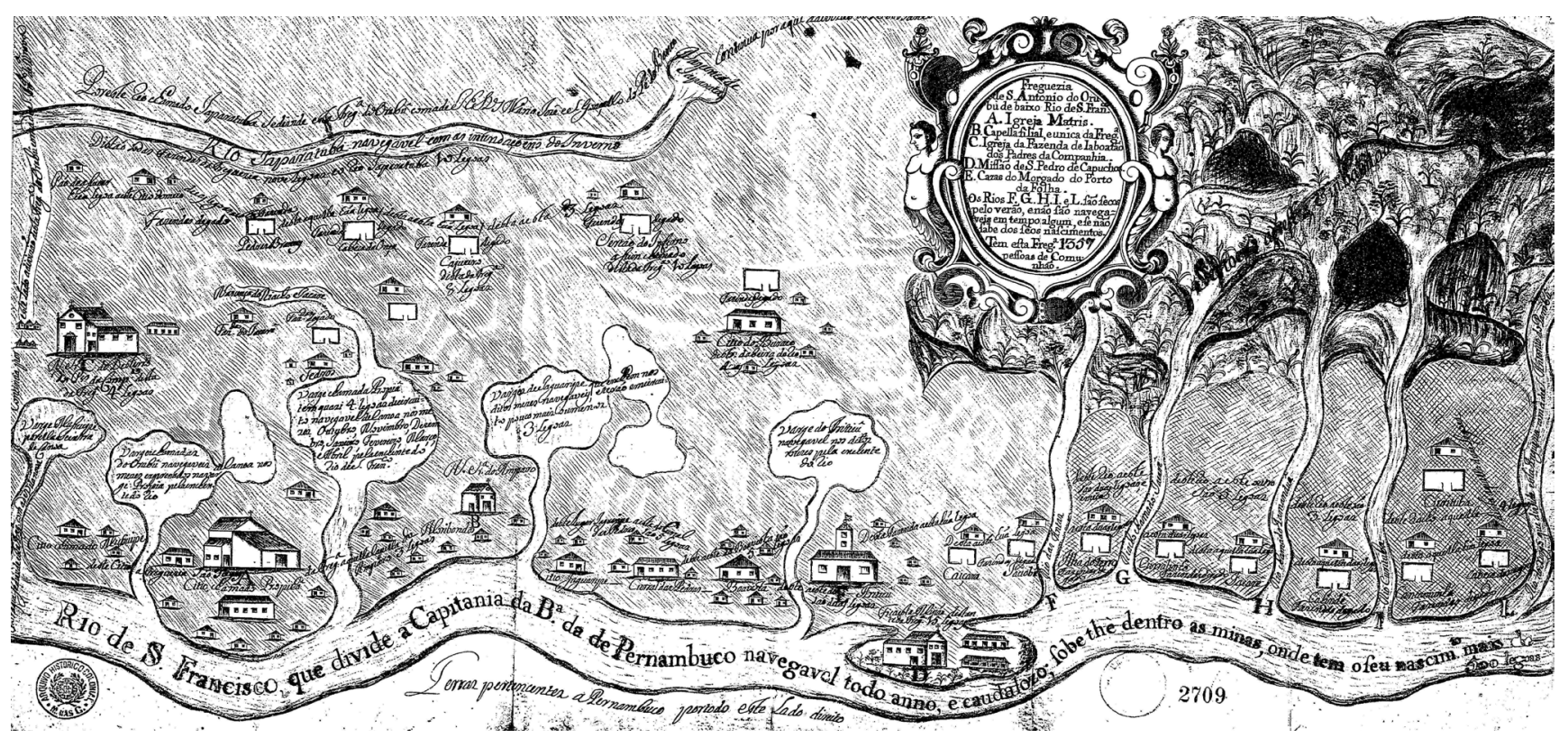

Figura 4 - Planta da freguesia de Santo Antônio do Urubu de Baixo do Rio São Francisco, no Arcebispado da Bahia. Imagem disponibilizada pelo Projeto Resgate Barão do Rio Branco.

(1761); Nossa Senhora da Conceição do Porto Real (1763) e Nossa Senhora da Grota do Juazeiro (1766).

Muito se deve às reformas políticas e sociais pombalinas para essa multiplicação. É dessa época a homologação do Diretório dos Índios (1757), que interferiu na emancipação e liberdade dos indígenas por meio da conversão, a priori, de alguns aldeamentos missioneiros em "lugar de índios" com o título de freguesia, assim como recomendado pelo bispo de Pernambuco, D. Francisco Xavier Aranha, às missões religiosas não elevadas ao foro de vila: "(...) sejam por nós erectas em Vigárias [sic.] que fazemos interinamente servir por clérigos seculares, até segunda resolução(...)" 81 .

Nos ulteriores reinados de D. Maria I e D. João VI, observamos uma redução no número de novas paróquias instituídas no território em análise. $\bigcirc$ fenômeno é exclusivo à capitania de Pernambuco, quando foi criada somente uma nova sede paroquial entre 1777 e 1822: São José do Carinhanha (1813). Supomos que um dos motivos para essa redução deva-se à queda econômica da pecuária sertaneja (ante o mercado interno), ocorrida no final do século XVIII e inicio dos Oitocentos. Por isso, os desígnios da Coroa voltaram-se para a produção algodoeira do Maranhão, Ceará, Rio Grande do Norte e Paraíba. Não nos surpreende, portanto, a má aceitação dos sertanejos à administração real:

Eis aqui, pois, El-rei nosso Senhor é mal visto nas províncias mais distantes de suas vistas, e como é também que o miserável público padece sacrificado aos caprichos e à rivalidade de certos homens, que por infelicidade representam os estado das cousas ${ }^{82}$
81. Cf. Ordem para a criação... (1929-1930, p. 344 349).

82. Cf. Roteiro de viagem que fez.... (1848, p. 60). 
83. Ver Bernard Lepetit (2001, p. 211)

84. Ver Dom Oscar de Oliveira (1964, p.148).

85. Ver Cláudia Damasceno Fonseca (2011, p. 100).

86. Agradeço a Cátedra Jaime Cortesão que tem cedido gentilmente a consulta aos cds do Projeto Resgate Barão do Rio Branco.

87. Elaboração do autor segundo informações encontradas em: Idéia da População... (1918. p. 05-116); Mapa das Igrejas... (s.d.); AHU_ACL_CU_015, Cx. 126, D. 9545.
É necessário realizar esse breve balanço temporal e geográfico (Figura 5), se quisermos verificar, no território, as materializações das decisões tomadas pelo Estado português, Igreja Católica e outros agentes envolvidos na colonização. Dessa maneira, entendemos o território como uma instituição social e política, dotado de lógicas mensuráveis ${ }^{83}$ mediante os variados eventos ali imbricados. Contudo, a simples interpretação do genérico tífulo de freguesia não basta para constatar os resultados materiais que nos referimos. É interessante observar as hierarquias honoríficas agregadas a essa categoria urbana, isto é, se uma paróquia era "colada" ou um "curato amovível". Um curato tinha sua administração responsabilizada a um padre designado pelo bispo e sustentado pelos fregueses, ao contrário de uma sede colada, cujos vigários eram nomeados pelo rei e subsidiados por honorários da Fazenda Real. Dom Oscar de Oliveira sugeriu que as paróquias de criação régia foram raras ao longo do período colonial ${ }^{84}$. $O$ governo tinha interesse em restringi-las, a fim de não despender com suas côngruas os dízimos que arrecadava. Na mesma linha que Oliveira, Cláudia Damasceno Fonseca opina que a Coroa não se interessou em conceder a todas as freguesias a qualidade de "colada", o que tudo indica que só criava paróquias colativas onde the convinha por algum motivo geopolíitico, e tal eleição não era oriunda do acaso85.

Por ora, dispomos de informações esparsas que não podem ser lidas como uma progressão temporal. Mas a documentação primária por nós compulsada - coletadas nos CDs do Projeto Resgate Barão do Rio Branco $^{86}$ e no acervo digital da Fundação da Biblioteca Nacional - tem-nos auxiliado a montar esse quebracabeças urbano, articulado pelas diferentes instâncias de poder (eclesiástica e civil) no que concerne às igrejas coladas ou aos curatos amovíveis. A tabela 2 reúne os dados inventariados até agora sobre as sedes paroquiais locadas no curso do rio São Francisco entre 1636 e 1813 :

\section{Tabela 2}

Curatos amovíveis e paróquias coladas implantadas na margem do rio São Francisco, $1636-1813^{87}$.

\begin{tabular}{|c|c|c|c|c|}
\hline $\begin{array}{l}\text { ANO DE } \\
\text { FUNDAÇÃO }\end{array}$ & FREGUESIA & $\begin{array}{l}\text { CURATO } \\
\text { AMOVIVELL }\end{array}$ & $\begin{array}{l}\text { COLATIVA } \\
\text { (ANO) }\end{array}$ & CAPITANIA \\
\hline 1636 & N. Sra. do Rosário & - & $X(?)$ & Pernambuco \\
\hline 1675 [?] & $\begin{array}{l}\text { N. Sra. da Conceição } \\
\text { do Cabrobó }\end{array}$ & - & $X(?)$ & Pernambuco \\
\hline 1679 & $\begin{array}{l}\text { Sto. Antônio do rio S. } \\
\text { Francisco }\end{array}$ & - & X (?) & Sergipe del Rey \\
\hline 1697 & $\begin{array}{l}\text { S. Francisco da Barra do } \\
\text { Rio Grande do Sul }\end{array}$ & $x$ & - & Pernambuco \\
\hline 1714 & $\begin{array}{c}\text { N. Sra. do Ó do Porto } \\
\text { da Folha }\end{array}$ & - & $x(1733)$ & Pernambuco \\
\hline
\end{tabular}




\begin{tabular}{|c|c|c|c|c|}
\hline 1714 & Sto. Antônio do Pambú & $x$ & - & Bahia \\
\hline 1718 & $\begin{array}{l}\text { Sto. Antônio do Urubu } \\
\text { de Cima }\end{array}$ & $x$ & - & Bahia \\
\hline 1718 & $\begin{array}{l}\text { Sto. Antônio do Urubu } \\
\text { de Baixo }\end{array}$ & $x$ & - & Sergipe del Rey \\
\hline 1755 & $\begin{array}{l}\text { Sto. Antônio do Pilão } \\
\text { Arcado }\end{array}$ & $x$ & - & Pernambuco \\
\hline 1755 & $\begin{array}{l}\text { São José da Barra do } \\
\text { Sento Sé }\end{array}$ & $x$ & - & Bahia \\
\hline 1761 & $\begin{array}{l}\text { N. Sra. da Saúde de } \\
\text { Tacaratú }\end{array}$ & $x$ & - & Pernambuco \\
\hline 1761 & N. Sra. da Assunção & $\begin{array}{l}\text { X (freguesia de } \\
\text { índios) }\end{array}$ & - & Pernambuco \\
\hline 1761 & Santa Maria & $\begin{array}{l}\text { X (freguesia de } \\
\text { índios) }\end{array}$ & - & Pernambuco \\
\hline 1761 & $\begin{array}{c}\text { S. João Batista do Sertão } \\
\text { dos Rodelas }\end{array}$ & $\begin{array}{l}\text { X (freguesia de } \\
\text { índios) }\end{array}$ & - & Bahia \\
\hline 1763 & $\begin{array}{l}\text { N. Sra. da Conceição } \\
\text { do Porto Real }\end{array}$ & $\begin{array}{l}\text { X (freguesia de } \\
\text { índios) }\end{array}$ & - & Pernambuco \\
\hline 1766 & $\begin{array}{l}\text { N. Sra. da Grota do } \\
\text { Juazeiro }\end{array}$ & $\begin{array}{l}\text { X (freguesia de } \\
\text { índios) }\end{array}$ & - & Bahia \\
\hline 1813 & S. José do Carinhanha & $x$ & - & Pernambuco \\
\hline
\end{tabular}

88. Ver Cláudia Damasceno (2011).

89. Cf. AHU_ACL_CU_ BAHIA, Cx. 15, D. 2711; AHU_ACL_CU_016, Cx. 2, D. 96.

Essa segunda tabela nos encaminha a algumas análises e indagações referentes às qualidades de curato amovível e igreja colada. A mais evidente revelase pelo expressivo número de curatos em relação às freguesias coladas: 13 versus quatro, isto é, somente $24 \%$ das paróquias eram sustentadas pelos cofres reais, enquanto que $76 \%$ estiveram subsidiadas pelo auxilio pecuniário dos fregueses. Se seguirmos o raciocínio de Fonseca, de que a Coroa elevou igrejas matrizes à dignidade de colada somente onde the convinha ${ }^{88}$, os dados da tabela equacionam desinteresse do rei de Portugal em seus domínios mais interioranos, por instituir apenas quatro freguesias ao título de colativas? Ainda não tivemos acesso a suficientes fontes documentais para responder detalhadamente esse questionamento. Todavia, a colação das quatro sedes paroquiais são complementares à política régia de controle fundiário, administrativo, fiscal e judiciário do território sertanejo. Por exemplo, a igreja de Cabrobó foi colada, a nosso ver, para moderar os avanços dominiais da poderosa Casa da Torre. Sendo assim, a colação dessa sede paroquial seria um interessante artifício para averiguar o cumprimento das leis de 20 de janeiro de 1699 e 23 de novembro de 1700. Assim consideramos, porque paróquias de outras capitanias foram coladas para cumprir o mesmo desígnio real. É o caso das freguesias de Nossa Senhora de Nazaré do Itapicuru de Cima e Nossa Senhora da Vitória (PI), ambas com colação contemporânea às leis sobreditas -1700 e 1701 respectivamente ${ }^{89}$. 




LEGENDA:

\section{Arcebispado da Bahia}

Bispado de Pernambuco

Principais rios
Freguesias oficializadas entre 1636 - 1679

- Freguesias oficializadas entre 1680 - 1718

Freguesias oficializadas entre 1750 - 1777

Freguesias oficializadas entre 1777 - 1822

Figura 5 - Sedes paroquiais oficializadas ao longo do rio São Francisco, entre 1636 e 1822. Desenho do autor, baseado em manuscritos do Projeto Resgate Barão do Rio Branco; Informação geral... (1906); Relação das igrejas paroquiais ... (s.d); Mapa das lgrejas do bispado de Pernambuco...; Freguesias da Bahia (1552 - 1857). 
No mesmo viés das colocações de Marx, outro exame pode ser 90. Cf. Murillo Marx (1991). levantado, referente ao papel urbanizador fornecido pelo Estado português à lgreja Católica, de reunir os homens à "sombra da cruz"90. De fato, não nos surpreende o expressivo índice de curatos ( 13 no total). O léxico associado ao foro de curato é "amovível", ou seja, aquilo que "se pode tirar quem o dá; não collado"91. Sabese que a instituição de um curato estava a cargo do bispo (diferentemente da colação, que era expediente real) e, portanto, os curas eram encomendados às suas respectivas igrejas paroquiais e re-designados para outras conforme o interesse da Igreja que, por seu turno, o será também da Coroa $^{92}$.

Portanto, a malha urbana de freguesias fora configurada pela Coroa em associação com seus oficiais eclesiásticos, notadamente os arcebispos e bispos. As paróquias cumpriram o duplo objetivo de gestoras do cotidiano espiritual e temporal dos ribeirinhos. Com a fundação das sedes paroquiais, eles passaram a usufruir, no dizer de Marx, das formalidades civis oferecidas pelo Estado93.

Entretanto, os jogos de poder, o controle sobre grandes glebas de terra e a costumeira prática de injustiças tornaram-se habituais no interior das capitanias da Bahia e Pernambuco. As sedes paroquiais, tomadas as devidas medidas, tentaram controlar os crimes e desequilíbrios sociais ocorridos entre os seus fregueses. Quiçá o "remédio" para tais instabilidades estaria na fundação de novas municipalidades, com seus vereadores e juízes competentes. No entanto, as vilas poderiam conceder a autonomia desejada aos morgados, fortalecendo-os, pois muitos de seus associados - procuradores, rendeiros e feitores residentes em alguma de suas fazendas - habilitavam-se a concorrer a um determinado cargo nos senados das câmaras. A Coroa, estando a par da realidade colonial, não se precipitou em fundar vilas nas povoações que almejassem o foro ou tivessem porte para tal promoção urbana, antes elegendo determinados arraiais ou freguesias, locados precisamente no território, convertendo-os em "julgados".

Pouco estudados pela historiografia, os "julgados", no momento de sua constituição, exigiam a nomeação de um "homem bom" da terra para ocupar o cargo de juiz ordinário (de vintena ou Hespadano), junto de um escrivão e um tesoureiro. Detinham uma circunscrição territorial precisa, reunindo um determinado número de moradores. Nos casos inventariados até agora, essa área, em geral, coincidiu com o território da paróquia no qual foi implantado. Para Cláudia Damasceno Fonseca, o julgado era uma circunscrição com autonomia judiciária parcial, por isso, sem jurisdição completa e autonomia administrativa, o que tornava dependente de uma vila vizinha. Seria a principal resolução adotada pelas autoridades régias para instalar estruturas judiciárias onde não se desejava implantar uma vila ${ }^{94}$.

Ao que parece, os primeiros aglomerados urbanos não oficializados e paróquias transformados em julgados surgiram na virada dos Seiscentos para os Setecentos. Em 1697, o bispo da diocese pernambucana, D. Francisco de Lima, após perceber as injustiças praticadas no sertão de seu bispado, sugeriu ao rei, D. Pedro II, a criação do cargo de juiz ordinário a cada cinco léguas, "(...) com 
95. Cf. Ernesto Ennes (1938, p. 350).

96. Cf. Informação geral... (1906, p. 343).

97. Ver AHU_ACL_CU_004, Cx. 1, D. 64 .

98. Ver AHU_ACL_CU_014, Cx. 26, D. 1993.

99. Ver AHU_ACL_CU_014, Cx. 26, D. 1993.

100. Ver AHU_ACL_ CU_018, Cx. 8, D. 506).

101. Ver AHU_ACL_CU_ BAHIA, Cx. 2, D. $169-172$.

102. Cf. AHU_ACL_CU_009, Cx. 11, D. 1138.

103. Cf. AHU_ACL_CU_009, Cx. 29, D. 2879.

104. Ver Aroldo de Azevedo (1956, p. 25).

105. Algumas dessas povoações tiveram suas nomeações alteradas com o transcorrer dos tempos. Por exemplo, a vila Nova de Santo Antônio do Rio São Francisco é conhecida hoje como Neópolis; Urubu chama-se Paratinga. Já as vilas de Santa Maria e Assunção perderam sua titulação de vila no século XIX devido ao seu diminuto desenvolvimento urbano. jurisdição de tirar devaças, tomar as denunciações, e querellaz nos delictos que aly se fizerem..." 95 . A resposta real veio em 1699, por meio da anteriormente citada Carta Régia de 20 de janeiro, na qual admoestava "(...) que em cada Freguezia das que tenho mandado formar pelos ditos Certões, haja um Juiz á similhança dos Juizes de vintena, que ha n'estes Reynos..."96. Com efeito, em 1699 esse ofício fora confirmado para as freguesias de Cabrobó e São Francisco da Barra do Rio Grande do Sul97.

As nomeações prosseguiram, dando princípio ao sistema urbano composto por julgados instituídos pelos sertões da Bahia e Pernambuco e outras capitanias. Em 1742, o Conselho Ultramarino emitiu um parecer favorável à criação da Comarca da Bahia da parte do Sul, também conhecida como Jacobina ${ }^{98}$. Nessa época, foram criados na dita comarca três julgados: Pambú, Asaroá e Sento Sé99. Anos antes, implantou-se, na banda pernambucana, o julgado de Pilão Arcado ${ }^{100}$. Como se vê no mapa da Figura 6 , às margens do curso do rio São Francisco encontramos tais aglomerações em números mais significativos e mais próximos entre si, se se compararmos com os outros localizados fora de sua ribeira. Não foi à toa tal escolha, por serem convergente aos planos políticos e sociais de Portugal. Além do combate às injustiças de diferentes níveis, a Coroa preocupou-se em estabelecer instrumentos regulatórios aos tributos de passagem para as minas de ouro e outras capitanias, buscando evitar o contrabando do ouro em pó cometido pelo caminho do rio São Francisco' ${ }^{101}$. A precisa localização dos seis julgados no vale sanfranciscano (Barra do Rio Grande do Sul, Pilão Arcado, Sento Sé, Asaroá, Pambú e Cabrobó) seria, aos olhos do Estado português, outro efetivo método para prevenir as prevaricações legais no que dizia respeito ao uso indevido do ouro (tanto extraído nas minas das Jacobinas como na capitania das Minas Gerais), ao não pagamento do obrigatório Quinto e às questões fundiárias envolvendo a Casa da Torre e outros grandes fazendeiros.

A oficialização dos julgados tentou acudir, dentro de suas limitações institucionais, os moradores mais interioranos e dispersos. Contudo, " (...) remedear as desordens que havia entre esta gente..." 102 requeria outra instância urbana - as vilas - porque às vistas do Conselho Ultramarino:

Quem tem experiençia do Brazil, e andou já alguns dos seus Certões, somente poderá saber a neçesid. ${ }^{e}$ que há de se multiplicarem as povoações, e de se criarem as justiças, para melhor comodo dos moradores, e se evitarem os muitos insultos, que nelles se cometem quotidianam.

te sem haver remedio para tanto mal, e que se havia algum hera o de se criarem Villas... ${ }^{103}$

De 1636, ano de fundação da vila de Penedo104, até 1822, data considerada como fim do período colonial, o Estado português implantou oito municipalidades ao longo do rio São Francisco - Penedo (1636); Vila Nova de Sto. Antônio do Rio São Francisco (1733); Urubu (1748); Barra (1752); Santa Maria (1761); Assunção (1761); Própria (1800) e Pilão Arcado (1810)105 cada uma dotada de especificidades, no que dizia respeito à conversão do seu status. 


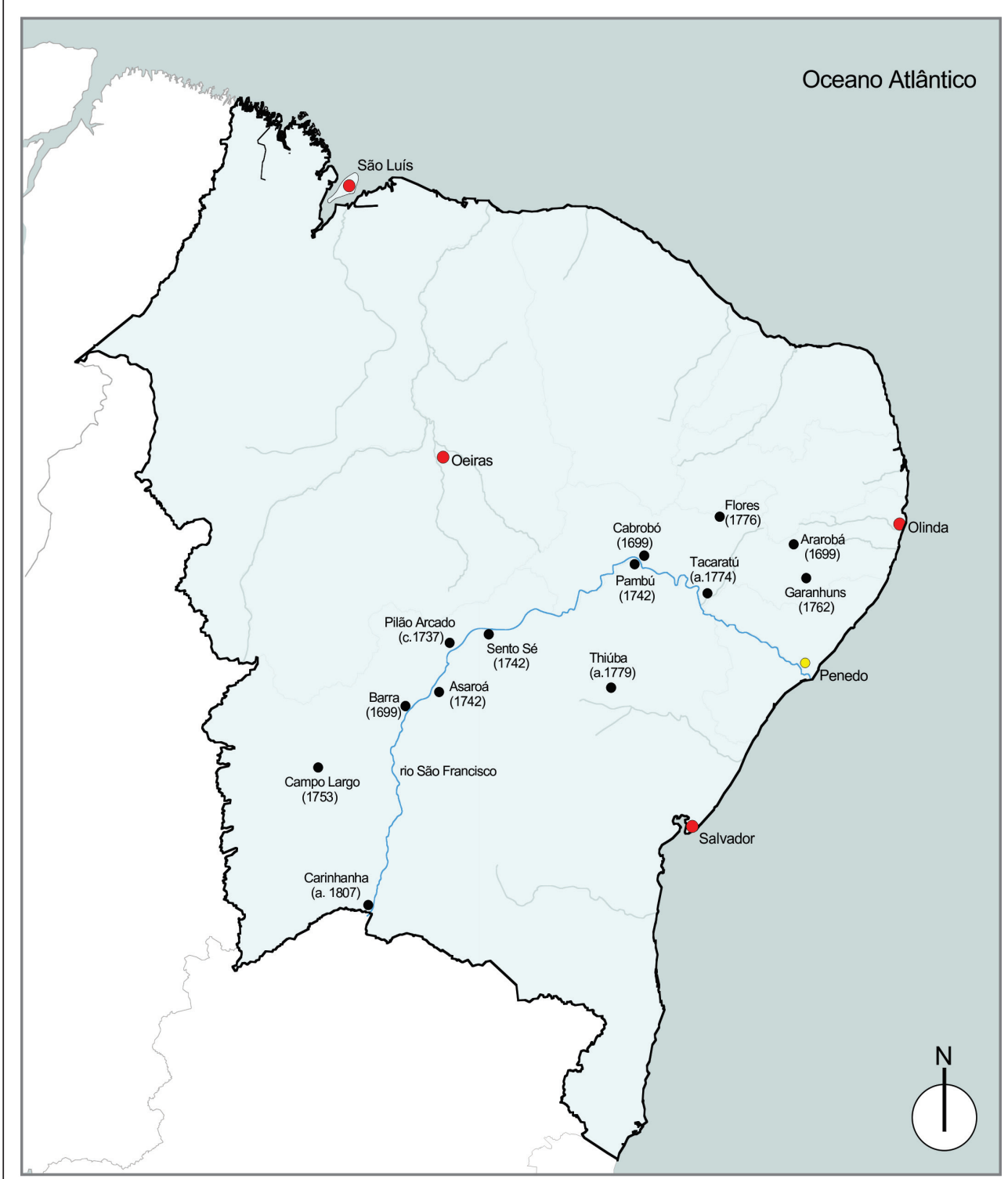

\section{LEGENDA:}

\section{Cidades}

Sede de Julgados (entre parêntesis a possível data de fundação)

\section{Principais rios}

Figura 6 - "Julgados" instituídos no vale do rio São Francisco, entre 1699 e 1807. Desenho do autor, baseado em manuscritos do Projeto Resgate Barão do Rio Branco e Informação geral.... (1906). 
106. Ver Dom Domingos de Loreto do Couto (1904, p. 167).

107. Ver AHU_ACL_CU_ BAHIA, Cx. 7, D. 1128.

108. AHU_ACL_CU_BAHIA, Cx. 7, D. 1130)
Porém, os documentos coevos asseveram o combate às injustiças como uma das causas basilares à concessão do título.

Situada no alto de um promontório, donde se sobressaem em sua paisagem urbana o convento dos franciscanos e a igreja matriz de Nossa Senhora do Rosário, a vila de Penedo terá um termo muito extenso, chegando a beirar na capitania de Minas Gerais. O seu fracionamento ocorreu somente em meados dos Setecentos, quando a Coroa decidiu elevar a freguesia da Barra do Rio Grande do Sul (atual Barra, BA) ao foro de vila ${ }^{106}$. Em seu termo existiram engenhos de açúcar e fazendas de criar gados. A navegação por sumacas dava-se desde a foz até o Porto das Piranhas, entreposto comercial cujas transações movimentaram Penedo com o sertão sanfranciscano e outros sertões nordestinos. Ademais, a localização da vila - oito léguas acima da "entrada" do São Francisco - facilitava as conexões mercantis entre distintas capitanias do Brasil Colônia, dando-a uma importante posição na hierarquia urbana dos Setecentos.

Em 1748 foi fundada, na Comarca da Jacobina, a segunda municipalidade do vale sanfranciscano - a vila do Urubu, hoje cidade de Paratinga (BA). Nessa altura, os descaminhos do ouro de Jacobina e de Minas Gerais eram frequentes. $O$ contrabando era realizado em grande parte por mascates, que transitavam a região para comerciar suas "fazendas" nos núcleos urbanos e nas estâncias de gado. A concessão do foro de vila à freguesia de Santo Antônio do Urubu de Cima daria à povoação o posto de "sentinela" contra tais descaminhos. Idem para a vila da Barra instituída em 1752. As comunicações entre as autoridades régias locadas no Brasil com Conselho Ultramarino trazem interessantes pistas sobre que ações deveriam ser tomadas para evitar o comércio ilegal do ouro e contra as injustiças cometidas na beira do São Francisco.

Em oficio a Diogo de Mendonça Corte Real, o Vice - rei do Estado do Brasil, Conde de Athouguia, apontou a necessidade de fundar a vila da Barra para evitar o extravio do ouro coletado das minas de Paracatu ${ }^{107}$. A emancipação daria à nova municipalidade autonomia para policiar o seu termo. Não precisaria, desse modo, solicitar tais medidas à vila a qual estava subordinada - Penedo, distante mais de 200 léguas. Um plano de patrulhamento das estradas fora elaborado pelas autoridades do governo "(...) que se ha de evitar, huma matéria de tantas conseqüências, quanto a que se seguem nos descaminhos que o ouro levou daquellas paragens, tanto para Pernambuco, como para Maranhão e Gram Pará $(\ldots . .)^{\prime \prime} 108$.

Analisando essas resoluções, notaremos que a Coroa não limitou, como uma caixa hermética, o distrito aurífero aos contornos físicos e oficiais da capitania de Minas Gerais, foi além. Virtualmente, as fronteiras das Gerais, como peças que se podem moldar facilmente, foram expandidas para outros territórios, como os sertões da Bahia, Pernambuco, Goiás e Piauí. Os vestígios materiais deixados por essas ações podem ser vistos por meio da malha civil de julgados e vilas, situados no rio São Francisco, assim como pelo estabelecimento de Registros fiscais na Comarca da Jacobina e nas passagens dos rios. 
No período pombalino, tais mudanças haviam sido mais expressivas, porque cunhava-se a emergência de uma nova identidade político-administrativa lusitana, iniciando uma reação de grande envergadura, que trouxe o Estado português ao eixo central do cenário político internacional ${ }^{109}$. Entre as decisões auferidas por D. José l e seu ministro, Sebastião José de Carvalho e Melo (conde de Oeiras, depois marquês de Pomball estavam a delimitação dos contornos dominiais das Coroas ibéricas; a expulsão dos padres da Companhia de Jesus de suas colônias ultramarinas, ocorrida de fato em 1759; e completa emancipação dos índios do Brasil, por intermédio das Leis de 06 e 07 de junho de 1755 e, sobremaneira, pelo Diretório dos Índios, homologado em 03 de maio de 1757.

A partir de 1761, sob interferência dos códigos enumerados no Diretório, a freguesia de Cabrobó presenciou a fundação de duas vilas: Assunção e Santa Maria, ambas oficializadas no sobredito ano, congregando índios de diferentes etnias e missões religiosas. Segundo Marcos Galindo, o pensamento do Diretório defendia a ordem ocidental com suas instituições (escola, igreja, cidade, comércio, entre outros) como instrumentos de civilidade, por cujos efeitos o indígena sairia da sua "barbaridade" para um degrau mais elevado na cultura colonial, tornando-se, portando, um ser produtivo da sociedade 110.

Nas novas vilas de índios, os neófitos ficaram "subgeitos ao estabelecido sistema de viver, avillados, subordinados as Leis com seus legítimos principais, e superiores havendo em cada villa hum director, hum pároco Branco e Câmara composta de juízes ordinários, e Vereadores, em parte Índios, e em parte Brancos..." 11 . Tal sistema de viver buscou homogeneizar a civilização dos nativos mediante a boa administração da justiça, agricultura, do comércio e do contato com o colono português. Ao invés de doutrinar, como faziam os missionários, o ideal seria civilizar ${ }^{112}$. Consequentemente, o ordenamento espacial das vilas, como núcleos urbanos planejados a priori, foi um recurso largamente propagado pela política de Pombal para a civilização dos nativos brasileiros. As vilas de Assunção e Santa Maria tiveram seu traçado seguindo a mesma morfologia linear e casas arruadas, "(...) com a mesma e boa perspectiva, e as ruas todas direitas, e largas..."113. Na opinião de Maria Helena Flexor, a regularidade do traçado foi o padrão estabelecido para a implantação das povoações criadas por Pombal, mais fácil de ser imposto e de se adequar às localidades tão distintas em que foram erguidas $^{114}$.

Depois da criação das duas vilas pombalinas nas margens médias do São Francisco, houve um hiato de 38 anos até que a Coroa concedesse o foro de vila a outra povoação. Em 1800, foi implantada na capitania de Sergipe a vila de Propriá, antes paróquia de Santo Antônio do Urubu de Baixo ${ }^{115}$. Infelizmente, encontramos poucas informações sobre a oficialização de Propriá.

Em seguida, o "Velho Chico" presenciou a fundação, em 1810, da vila de Pilão Arcado (hoje em ruínas), localizada na banda pernambucana. Contemporânea à instituição dessa vila, tivemos a constituição da Comarca do Sertão de Pernambuco, com sede de ouvidoria também na recém-fundada vila de
109. Ver Marcos Galindo (2011, p. 177).

110. Ver Marcos Galindo (2011, p. 188).

111. Cf. AHU_ACL_CU_014, Cx. 41, D. 2853.

112. Ver Maria Helena Flexor (1989, p. 10).

113. Apud Marcos Galindo (2011, p. 188).

114. Ver Maria Helena Flexor (1989, p. 20).

115. Dados coletados em <http://www.ibge.gov.br>, acesso em 01/05/2013. 
116. Ver Joaquim Veríssimo Serrão (1983, p. 167).

117. Ver Alvará com força de Lei.... (s.d.).
Flores do Pajeú. Para o historiador português Joaquim Veríssimo Serrão ${ }^{16}$, a partir da primeira década dos Oitocentos, Portugal desenvolveu cada vez mais a organização judicial no Brasil. Aproveitou a criação simultânea de vilas, correspondendo aos pedidos das câmaras e ao sentir da população. Queria D. João Vl que seus vassalos, por meio dos novos municípios, gozassem de sossego e bem públicos, ocasionando a pronta e atendida administração de justiça ${ }^{117}$.

Este breve panorama político, econômico, social e religioso pretendeu introduzir algumas questões da paisagem material e urbanização encerradas no curso do rio São Francisco, o rio dos currais. As considerações expostas não são peremptórias, lacunas existem e persistirão. Entendemos que não se tratou de um fenômeno simples, pelo contrário, a rede de relações e os fluxos fundamentados pelo gado elaboraram uma intricada rede de caminhos, pousos e fazendas, viabilizando o mercado interno voltado ao abastecimento dos principais centros urbanos da colônia (São Luís, Recife, Olinda, Salvador, Rio de Janeiro e arraiais mineiros). A ascensão da teia paroquial, relativamente densa em certas partes da região, e dispersa em outras, oficializou o povoamento dos vastos sertões, sendo o preâmbulo da teia civil de julgados e vilas, organizando um sistema com funções hierárquicas determinadas no ultramar, nos governos das capitanias e nas câmaras das vilas sertanejas.

\section{REFERÊNCIAS}

\section{FONTES TEXTUAIS PRIMÁRIAS MANUSCRITAS}

Arquivo Histórico Ultramarino, Lisboa

AHU_ACL_CU_004, Cx. 1, D. 64.

AHU_ACL_CU_009, Cx. 11, D. 1138.

AHU_ACL_CU_009, Cx. 29, D. 2879.

AHU_ACL_CU_009, Cx. 29, D. 2978.

AHU_ACL_CU_009, Cx. 33, D. 3343.

AHU_ACL_CU_014, Cx. 26, D. 1993.

AHU_ACL_CU_014, Cx. 41, D. 2853.

AHU_ACL_CU_015, Cx. 17, D. 1732.

AHU_ACL_CU_015, Cx. 18, D. 1764.

AHU_ACL_CU_015, Cx. 18, D. 1771. 


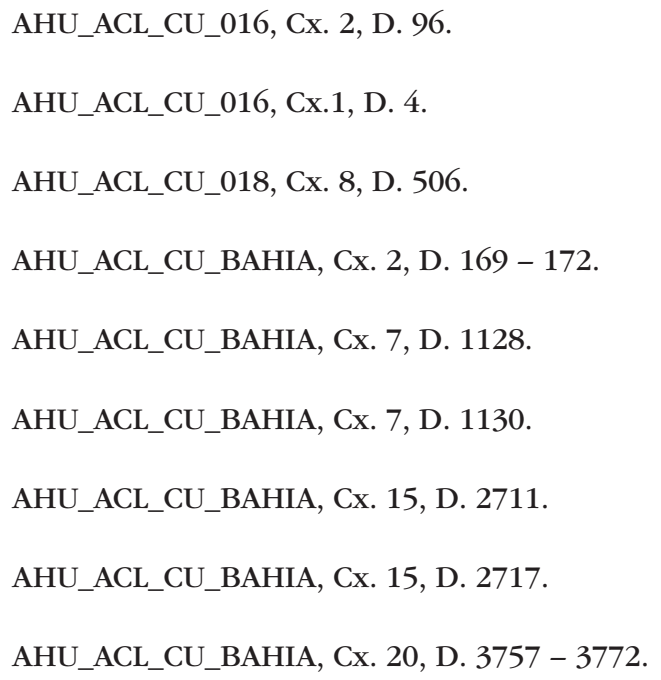

Fundação Biblioteca Nacional / Seção de Manuscritos, Rio de Janeiro

MAPA das Igrejas do bispado de Pernambuco, suas côngruas e rendimentos; I - 31, 24, 011. Disponível em http://www.bn.br, acesso em 25/01/2013.

RELAÇÃO de igrejas paroquiais referentes ao bispado de Pernambuco e dos dizimos repassados pelas mesmas"; I - 32, 33, 036.

Arquivo Público do Estado da Babia, Salvador

FREGUESIAS da Babia (1552 - 1857); maço 5247.

\section{FONTES TEXTUAIS PRIMÁRIAS IMPRESSAS}

ÁLVARA com força de Lei, pelo qual Vossa Alteza Real Ha por bem crear a nova Comarca do Sertão de Pernambuco, sesanexando da antiga algumas Villas, e Julgados; e Erigir em Villas as Povoações de Pilão Arcado, e Flores na Ribeira do Pajabu; na forma acima exposta. Disponível em www.archive.org, acesso em 21/09/2012.

ANTONIL, André João. Cultura e opulência do Brasil. $3^{\text {a }}$ ed. Belo Horizonte: Itatiaia; São Paulo: Edusp, 1982. (Coleção Reconquista Brasil).

BLUTEAU, Raphael, S. J. Vocabulário português, e latino...Coimbra, Real Collegio das Artes da Companhia de Jesus, 1712 - 1719. Disponível em <http://www.brasiliana.usp.br>, acesso em 28/04/2013.

COUTO, D. Domingos do Loreto. Desagravos do Brazil e Glorias de Pernambuco. Anais da Biblioteca Nacional do Rio de Janeiro, Rio de Janeiro, v. 26, 1902. 
IDÉIA da População da Capitania de pernambuco, e das annexas, extenção de suas costas, Rios, e Povoações notaveis, Agricultura, numero dos Engenhos, Contractos, e Redimentos Reaes, augmento que estes tem tido \&.\& desde o anno de $1774 \mathrm{em}$ que tomou posse do Governo das mesmas Capitanias o Governador e Capitam General Jozé Cézar de Menezes. Annaes da Bibliotheca Nacional, Rio de Janeiro, v. 40,. 1918.

INFORMAÇÃO sobre as minas do Brasil. Anais da Biblioteca Nacional, Rio de Janeiro,.v. 57, p.159-186, 1935.

INFORMAÇÃO Geral da Capitania de Pernambuco, 1749. Anais da Biblioteca Nacional, Rio de Janeiro, v. 28, p. 118-483, 1906.

NANTES, Pe. Martinho de. Relação de uma missão no São Francisco. São Paulo: Ed. Nacional, 1979.

ORDEM para a criação das Villas e Vigararias de Índios. Arquivo da matriz de Viçosa, livro de registro ${ }^{\circ}$ 02. Revista do Instituto do Ceará, Fortaleza, p. 344-349,1929-1930.

ROTEIRO de viagem que fez o Capitão Francisco de Paula Ribeiro às fronteiras da Capitania do Maranhão e Goyaz no anno de 1815 em serviço de S. M. Fidelissíma. Revista do Instituto Histórico e Geográfico Brasileiro, Rio de Janeiro, t. 10, p. 05-107, 1848.

SALVADOR, frei Vicente de. História do Brasil: 1500 - 1627. 7 ed. Belo Horizonte: Itatiaia; São Paulo: Edusp, 1982.

SAMPAIO, Theodoro. O rio São Francisco trechos de um diário de viagem e a Chapada da Diamantina. São Paulo: Escolas Profissionaes Salesianas, 1905.

SILVA, Antonio de Moraes. Diccionario da Lingua portugueza - recompilado dos vocabularios impressos ate agora, e nesta segunda edição novamente emendado e muito acrescentado. Lisboa: Typographia Lacerdina, 1813. Disponível em <http://www.Brasiliana.usp.br.>, acesso em $27 / 04 / 2013$.

VIDE, Sebastião Monteiro da. Constituições Primeiras do Arcebispado da Babia, feitas e ordenadas pelo ilustrissimo e reverendíssimo D. Sebastião Monteiro da Vide. Brasília: Senado Federal, Conselho Editorial, 2011.

VILHENA, Luiz dos Santos. Recopilação de Noticias Soteropolitanas, e Brasilicas, Tomo II. 1802. Disponivel em <http://www.bn.br>, acesso em 01/11/2011.

\section{FONTES ICONOGRÁFICAS}

D’ANVILLE, Jean-Baptiste Bourguignon. Carte qui répresente la partie meridionale du Brésil et du Peru, le Chili septentrional et le Paraguay (...), s.d. Acervo da Fundação Biblioteca Nacional, Rio de Janeiro. Disponível em <http://www.br.br>, acesso em 27/04/2011.

MAPA da Comarca da Babia de Todos os Santos sua divisão desde o rio Jiquiriça athé o rio Real pela parte Norte, s.d. Acervo da Fundação Biblioteca Nacional, Rio de Janeiro. Disponível em <http://www.bn.br>, acesso em 02/06/2010.

VILHENA, Luis dos Santos. Planta geografica do que se tem melhor averiguado nas Commarcas da Babia (...), s.d.. Acervo da Fundação Biblioteca Nacional, Rio de Janeiro, p. 13. Disponível em <http://www.bn.br>, acesso em 31/10/2011. 
CARTE geografica del Bresil (1740). Acervo da Fundação Biblioteca Nacional, Rio de Janeiro. Disponível em <http://www.br.br>, acesso em 05/06/2010.

VINGBOONS, Johannes. Kaart van het fort't week graaf Mauritis Van Nassauw heeft doen leggen aan de rivier St. Francisco den 29 maart 16. Plattegrand van fort Mauritis bij Rio Santo Francisco, Brazilië. Acervo do Nationaal Archief, Haia, Países Baixos. Disponível em <www. nationaalarchief.nl>, acesso em 05/05/2013.

PLANTA da freguesia de Santo Antônio do Urubu de Baixo do Rio São Francisco, no Arcebispado da Bahia. Acervo do Arquivo Histórico Ultramarino (AHU_ACL_CU_Cx. 15, D. 2709), reprodução disponível em cd pelo Projeto Resgate Barão do Rio Branco.

\section{LIVROS, ARTIGOS E DISSERTAÇÕES}

ABREU, Capistrano de. Capítulos de História colonial, 1500 - 1800, $7^{\text {a }}$ ed. São Paulo: Publifolha, 2000.

ANDRADE, Amélia Aguiar. Horizontes urbanos medievais. Lisboa: Livros Horizonte, 2003.

ANDRADE, Manuel Correia de. O processo de ocupação do espaço regional do Nordeste, $2^{\mathrm{a}}$ ed. Recife: SUDENE, 1979.

ARRAES, Damião Esdras A.. Curral de reses, curral de almas: urbanização do sertão nordestino entre os séculos XVII e XIX. Dissertação (Mestrado), Universidade de São Paulo / Faculdade de Arquitetura e Urbanismo, São Paulo, 2012.

AZEVEDO, Aroldo de. Vilas e cidades do Brasil colonial: ensaio de geografia urbana retrospectiva. São Paulo: FFLCH - USP, 1956.

AZZI, Riolando. A instituição eclesiástica durante a primeira época colonial. In: HORNAERT, Eduardo. História da Igreja no Brasil: ensaio de interpretação a partir do povo: primeira época, Período colonial, $5^{\text {a }}$ ed. Petrópolis: Vozes, 2008. p. 155-234.

BURKE, Peter. O que é História cultural?. Rio de Janeiro: Jorge Zahar, 2005.

DANTAS, Monica Duarte. Fronteiras movediças: a Comarca da Itapicurú e a formação do arraial de Canudos. São Paulo: Hucitec; FAPESP, 2007.

ENNES, Ernesto. As guerras nos Palmares. Rio de Janeiro: Cia. Editora Nacional, 1938.

FLEXOR, Maria Helena. Os núcleos urbanos planejados do séculos XVIII: Porto Seguro e São Paulo. Salvador: Centro de Estudos Baianos da UFBA, 1989.

FONSECA, Cláudia Damasceno. Arraiais e vilas d'el rei: espaço e poder nas Minas setecentistas. Belo Horizonte: Editora UFMG, 2011.

FONSECA, João Justiniano da. Rodelas: curraleiros, índios e missionários. Salvador, 1996.

GALINDO, Marcos. A submergência Tapuia. In: OLIVEIRA, João Pacheco de. (org.). A presença indígena no Nordeste: processos de territorialização, modos de reconhecimento e regimes de memória. Rio de Janeiro: Contra Capa, 2011. p. 167 - 215

GOULART, José Alípio. A formação da zona pecuária nordestina. Revista do Instituto Histórico e Geográfico Brasileiro, Rio de Janeiro, v. 259, p. 16-26, abr.-jun., 1963. 
HOLANDA, Sérgio Buarque de. História da civilização brasileira. t.I, v. II. São Paulo: Difusão Européia do Livro, 1960.

LEITE, Pe. Serafim. História da Companbia de Jesus no Brasil. t. V, 1. I. Rio de Janeiro: Civilização Brasileira, 1938.

LEPETIT, Bernard. Por uma nova história urbana. Revisão crítica e apresentação de Heliana Angotti Salgueiro. São Paulo: Edusp, 2001.

LIMA, Ebion. "As missões oratorianas no Brasil: informação sobre as missões oratorianas no Nordeste”. Revista do Instituto Histórico e Geográfico Brasileiro, Rio de Janeiro, n. 323, p. 69118, abr.-jun., 1979.

LIMA SOBRINHO, Barbosa. Capistrano de Abreu e o povoamento do sertão pernambucano. Revista do Instituto Arqueológico, Histórico e Geográfico de Pernambuco, Recife, v. 50, p. 9-49, 1978.

MAGALHÃES, Basílio de. Expansão geográfica do Brasil colonial, $3^{\text {a }}$ ed. Rio de Janeiro: Epasa, 1944.

MARX, Murillo. Cidades no Brasil, terra de quem?. São Paulo: Edusp;Nobel, 1991.

MELLO NETO, José Antônio Gonsalves de. Três roteiros de penetração do território pernambucano (1733 e 1802). Recife: UFPE, 1966.

OLIVEIRA, Dom Oscar. Os dízimos eclesiásticos do Brasil nos períodos da Colônia e do Império. Belo Horizonte: UFMG, 1964.

OlIVEIRA, João Pacheco de (org.). A presença indígena no Nordeste: processo de territorialização, modos de reconhecimento e regimes de memória. Rio de Janeiro: Contra Capa, 2011. p. 690-707.

POMPA, Cristina. História de um desaparecimento anunciado: as aldeias missionárias do São Francisco, séculos XVIII - XIX. In: OLIVEIRA, João Pacheco de (org.). A presença indígena no Nordeste: processos de territorialização, modos de reconhecimento e regimes de memória. Rio de Janeiro: Contra Capa, 2011. p. 267-292

PRADO Jr., Caio. História econômica do Brasil. São Paulo: Brasiliense, 2000.

REIS FILHO, Nestor Goulart. Contribuição ao estudo da evolução urbana do Brasil (1500/1720), $2^{\text {a }}$ ed. São Paulo: Pini, 2000.

SANTOS, Paulo F. Formação de cidades no Brasil colonial. Rio de Janeiro: Editora da UFRJ, 2001.

SANTOS, Milton. A natureza do espaço: técnica e tempo, razão e emoção, $4^{\mathrm{a}}$ ed. São Paulo: Edusp, 2009

SERRÃO, Joaquim Veríssimo. História de Portugal. v. VII (A instauração do liberalismo: 1807 - 1832). Lisboa: Editora Verbo, 1983.

SILVA, Jacionira Coelho. Arqueologia no médio São Francisco: índigenas, vaqueiros e missionários. Tese (doutorado), Universidade Federal de Pernambuco, Recife, 2003.

STUDART FILHO, Carlos. Vias de comunicação do Ceará colonial. Revista do Instituto do Ceará, Fortaleza, t. 51, p. 15-47, 1937. 


\section{SÍTIOS CONSULTADOS:}

$<$ http://www.arquidiocesesalvador.org.br>, acesso em 26/04/2013.

<http://www.ibge.gov.br>, acesso em 01/05/2013.

<http://www.brasiliana.usp.br>, acesso em 27/04/2013.

$<$ http://www.bnportugal.pt>, acesso em 26/04/2013.

<http://www.bne.es>, acesso em 28/04/2013.

<http://www.gahetna.nl>, acesso em 27/04/2013.

$<$ http://www.ibge.gov.br>, acesso em 01/05/2013

<http://www.archive.org>, acesso em 21/09/2013.

$<$ http://www.bn.br>, acesso desde 01/03/2011.

<http://www.nationaalarchief.nl>, acesso em 05/05/2013.

Artigo apresentado em 04/06/2013. Aprovado em 23/12/2013. 